\title{
Város és vonzáskörzete: gazdasági kapcsolatrendszer és növekedés Vázlat a győri jármüipari körzet regionális makromodelljének kidolgozásához
}

\section{City and agglomeration: economic relations and growth}

\author{
KOPPÁNY KRISZTIÁN, KOVÁCS NORBERT, \\ SZABÓ DÁNIEL RÓBERT
}

KOPPÁNY Krisztián: egyetemi adjunktus, Széchenyi István Egyetem, Nemzetközi és Elméleti Gazdaságtan Tanszék, Győr; koppanyk@sze.hu

KOVÁcS Norbert: egyetemi adjunktus, Széchenyi István Egyetem, Nemzetközi és Elméleti Gazdaságtan Tanszék, Győr; kovacsn@sze.hu

SZABÓ Dániel Róbert: egyetemi tanársegéd, Széchenyi István Egyetem, Gazdasági Elemzések Tanszék, Győr; szabodr@sze.hu

KULCSSZAVAK: régió, input-output modell, társadalmi elszámolási mátrix, multiplikátor, növekedés

ABSZTRAKT: A makrogazdasági összefüggések feltárása, számszerü leírása nemcsak nemzeti, hanem regionális szinten is nagy jelentőséggel bír, különösen egy olyan célzott térségi fejlesztési koncepció esetében, mint a győri járműipari körzet. A régió össztermelése, ágazati szintre bontott kibocsátása, jövedelmei, végső felhasználása és hozzáadott értéke kulcsfontosságú elemei a helyi fejlődésnek, gazdasági növekedésnek. Egy regionális előrejelzésre és tervezésre alkalmas makromodell nélkülözhetetlen eszköze a körzeti fejlesztési irány megvalósításának, a részletek kidolgozásának, a várható hatások, változások számszerüsítésének. Milyen tovagyürüző hatásai lehetnek a térségben megvalósuló vállalati fejlesztéseknek, állami beruházásoknak, az itt hasznosuló helyi, központi kormányzati vagy uniós forrásoknak, új gazdasági szereplők megjelenésének vagy megszünésének? Hogyan hat a helyi gazdaságra a végső fogyasztás szintjének vagy szerkezetének, a fogyasztás vagy a termelés importigényének, a régión kívülről történő beszállítás igényének vagy a térség exportteljesítményének a változása? Milyen hatással jár a technológiai átalakulás, a vállalatok beszállítói kapcsolatainak a módosulása? Pozitív nettó eredménnyel jár-e a helyi önkormányzat és a helyi gazdaság szempontjából bizonyos adókedvezmények vagy más gazdaságpolitikai ösztönzők alkalmazása? Ilyen és ezekhez hasonló kérdésekre kaphatunk választ a modell segítségével. Az alkalmazási lehetőségek szerteágazóak, s ennek megfelelően széles körü a potenciális felhasználók tábora is. A modellszámítások kiválóan hasznosíthatók hatástanulmányok készítésekor, s nemcsak a regionális kormányzat, hanem a magánszektor döntéseinek előkészítését is támogatják. A gazdaságszervező erő számszerű kimutatása segíthet vállalkozások, nonprofit szervezetek vagy akár fogyasztók alkupozíciójának helyes megítélésében és érvényesítésében is.

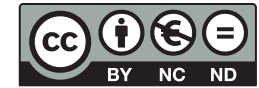


Krisztián KOPPÁNY: assistant professor, Department of International and Theoretical Economics, Széchenyi István University, Győr; koppanyk@sze.hu

Norbert KOVÁCS: assistant professor, Department of International and Theoretical Economics, Széchenyi István University, Győr; kovacsn@sze.hu

Dániel Róbert SZABÓ: assistant lecturer, Department of Economic Analyses, Széchenyi István University, Györ; szabodr@sze.hu

KEYWORDS: region, input-output model, social accounting matrix, multiplier, growth

ABSTRACT: Economic analysis of an area, exploring its macroeconomic relations using quantitative methods, can have a great importance on both national and regional levels. The authors' long-term objective is to develop a regional macroeconomic model calibrated for the Regional Automotive District of Györ. The region's total production, output, final demand and value added disaggregated on sectoral-territorial level are the key elements of local development and economic growth. A macroeconomic model, describing their relations and expected values, suitable for regional forecasting and planning can be an essential tool for the development of the district, capable of elaborating its details and forecasting expected quantified effects.

What kind of multiplicative effects can the development of the businesses, governance, investments, local, governmental and EU resources utilized in the area, appearance and disappearance of actors have on the economy of the region? How would the local economy be affected by the change of the final consumption's level and structure, the import demand of the consumption and production for supply from outside the region or the country, or the increase of the export? What kind of impact could the technological changes or the shift of the supplier relations have on a region? Does the application of certain local tax allowances or other incentives have a positive net result for the governance and economy? Answers to these and other similar questions could be found with this model. The applications and the groups of potential users can be diverse. Calculations with the model can be utilized not only in impact studies, but also as a decision support tool for the actors of the regional governance or private sector. It can also be helpful for the assessment and enforcement of the bargaining power of businesses, non-profit organizations and consumers as well.

In our study we try to put forth the foundations of a macroeconomic model, describing the relations and settings of the key variables from the first paragraph, preparing a multi-year research project that requires concentrated resources and profound analyses. The result of this research will be an analytic framework, precisely calibrated for Györ and its agglomeration, suitable for use in practice. The basic model discussed here is only a first draft. This initial system has been tested with arbitrary parameters and proven to be suitable for regional macroeconomic forecasting. Although a full data collection and calibration couldn't be accomplished with the resources and time available, we began to supply the system with real data and develop an underlying database. As the essential results of the corporate and household surveys utilized by the whole automotive district project aren't submitted yet, we can only incorporate them in the next stages.

In the first section we summarize the components of the theoretical background for the framework of the proposed model. In the second part, we present regional applications of the model. Using these, in the third section, we lay down a system suitable for describing the regional macroeconomy of the Györ automotive district. Finally, by providing more details, we discuss the requirements and the possible directions for further development of our model. 


\section{A tanulmány célja és felépítése}

Tanulmányukban egy regionális makrogazdasági modell alapjait igyekszünk lefektetni, előkészítve ezzel egy várhatóan több éves kifutású, az összefüggések mélyére hatoló, koncentrált erőforrásokat igénylő kutatási programot. Az itt bemutatott alapmodell egyelőre csupán egy váz, de logikailag átgondolt, zárt rendszert alkotó, önkényesen megválasztott paraméterekkel már kipróbált, regionális elemzésre alkalmas rendszer váza.

A tanulmány első részében a javasolt modellkeret elméleti hátterét, közgazdasági építőkockáit foglaljuk össze, a másodikban pedig ezek regionális alkalmazásaira mutatunk példákat. A harmadik részben fektetjük le azt a vázat, amelyet a győri járműipari körzet makrogazdaságának - s tulajdonképpen bármely nagyvárosnak és vonzáskörzetének - leírására alkalmasnak gondolunk. A tanulmány végén részletesebben kifejtjük a továbbfejlesztés igényét, irányait és eszközeit.

\section{Építőkockák: az elméleti háttér}

Elemzési keretünk a következő komponensekből épül fel: input-output modell, termelési multiplikátorok, társadalmi elszámolási mátrix, valamint kiadási-jövedelmi multiplikátor. A tanulmány első részében ezeket mutatjuk be röviden.

\section{Ágazati kapcsolatok mérlege, input-output táblák}

Modellünk keresletvezérelt. A végső kereslet elemeit a háztartások, a nonprofit intézmények és a kormányzati szektor végső fogyasztási kiadásai, a magán- és kormányzati beruházási kiadások, valamint az export jelentik. A keresleti komponenseket ágazati bontásban kezeljük, s első lépésben azt keressük, hogy a végső felhasználáshoz milyen ágazati termelésre, bruttó kibocsátásra van szükség.

A specializáció magas szintjével jellemezhető modern gazdaság termelöszolgáltató szektorának szereplői kibocsátásuk előállításához jellemzően más ágazatok termelését is felhasználják. Beszállítói kapcsolatok bonyolult hálózata szövi át a gazdaság gépezetét, a végső kereslet kielégítése hosszú, sokszereplős értékláncokon keresztül valósul meg. A végső felhasználóval a termelő szektornak csak egy része, az értéklánc végén elhelyezkedő vállalatok kerülnek kapcsolatba. A láncolat minden résztvevője a másoktól beszerzett anyagok, igénybe vett szolgáltatások, vagyis a termelő felhasználás értékéhez az általa elvégzett tevékenységgel járul hozzá. A hozzáadott értékkel növelt kibocsátás az értéklánc következő szereplőjénél aztán ismét közbülső fogyasztásként, termelő felhasználásként jelentkezik, egészen addig, amíg a termék el nem jut a végső felhasználóhoz. 
A végső kereslet kielégítéséhez szükséges bruttó kibocsátás meghatározásához figyelembe kell vennünk a technológiai sajátosságokat, az egyes ágazatok ennek megfelelően kialakított beszállítói kapcsolatait, s az ezek által létrejövő termelő célú kibocsátásokat és felhasználásokat. Ezek meghatározására szolgál az input-output tábla vagy - a hazai közgazdasági szakzsargonban elterjedt szóhasználat szerint - ágazati kapcsolatok mérlege (ÁKM), valamint az erre épülö, mátrixalgebrán alapuló input-output (I-O) elemzés.

Input-output modelleket már az 1930-as években kidolgoztak, amelyben úttörő szerepe volt Wassily Wassilyovich Leontief orosz származású, Nobel-díjas közgazdásznak. A ma relatíve egyszerűnek tekinthető matematikai apparátus ezekben az időkben még rendkívül komoly számítási feladatot jelentett. Ez a gyakorlati alkalmazást korlátozó tényező 25-30 évvel később, a számítógép elterjedésével és fejlődésével fokozatosan elhárult. Az 1950-es és 1960-as években az input-output volt a legelterjedtebb kvantitatív makrogazdasági modell, mára azonban használata - talán kissé indokolatlanul - háttérbe szorult (Augusztinovics 1996).

Az input-output táblázat logikája, felépítése könnyen megérthető. ${ }^{1} \mathrm{Ha}$ a táblázatot soronként olvassuk, akkor az oldalrovatban feltüntetett kibocsátó ágazat termékeinek hasznosulását követhetjük nyomon. Ha oszlopok szerint tekintjük a számokat, akkor az adott ágazat összes kibocsátásához szükséges felhasználásokat láthatjuk. A vállalatok költségeit, ráfordításait egyrészt a belföldi és külföldi beszállítók számlái adják. Ezen kívül alkalmazottaiknak munkabért, a bérek után járulékokat fizetnek, értékcsökkenést számolnak el eszközeik után, adóznak, valamint tulajdonosaik számára jövedelmeket termelnek. Ezek a tételek adják a hozzáadott értéket, amelyet a termelő felhasználáshoz hozzáadva kapjuk az egyes szektorok, illetve a gazdaság egészének bruttó kibocsátását. A gazdasági ágak legalsó sorban szereplő kibocsátásai pontosan megegyeznek az ágazathoz kapcsolódó felhasználásokkal. Ez biztosítja a táblázat konzisztenciáját: minden kibocsátás hasznosul valamilyen formában (ha másként nem, készletnövekményként a bruttó felhalmozáson belül).

Az input-output tábla hozzáadottérték-komponenseket tartalmazó bal alsó részét alsó szárnynak, a végső felhasználás elemeit tartalmazó jobboldali részét oldalszárnynak, az egyes szektorok egymással való beszállítói kapcsolatát kifejező, a táblázat bal felső részében elhelyezkedő négyzetes mátrixot pedig belső négyzetnek nevezzük. Ez jelenti az input-output táblázat matematikai elemzés szempontjából legfontosabb részét.

\section{Az ágazati kapcsolati mérleg matematikai elemzése, a termelési multiplikátorok}

Az input-output modell a marxi, neoklasszikus, neoricardiánus elméletek keretében egyaránt értelmezett lineáris gazdasági összefüggésekre épít. A linearitás feltételezése teszi lehetővé és szükségessé a nemnegatív négyzetes mátrixokra vonatkozó matematikai eredmények alkalmazását (Zalai 2000). 
Mit is jelentenek a lineáris összefüggések? Ha a táblázat minden egyes elemét elosztjuk az adott oszlop összegével, akkor megkapjuk, hogy egységnyi kibocsátáshoz hány egység azonos vagy más szektorból származó beszállításra, hány egység importra, hány egység munkabérre és járulékra, tőkejövedelemre és kormányzati adóbevételre van szükség. Az oldalszárny elemeinél a végső felhasználás szektorális arányait kapjuk. A linearitás azt jelenti, hogy a modellben minden ezen arányok szerint változik.

A közvetlen igények újabb és újabb termelésnövekményt indukálnak. A közvetlen ráfordítási együtthatókkal felírt belső mátrix lineáris technológiai összefüggéseinek megfelelően egy multiplikatív folyamat fut végig a gazdasági rendszerben, a bruttó kibocsátás a végső felhasználás kezdeti változásánál nagyobb mértékben módosul. Ezt szemlélteti az 1. ábra, amely a végső felhasználás 1 Ft-os növekedésének tovagyűrüző hatásait mutatja. Az oszlopdiagramon ábrázolt végtelen sorozat elemeinek (ebből az ábrán csak hatot tüntettünk fel) összege adja a bruttó kibocsátás termelési multiplikátorát. Amennyiben arra vagyunk kíváncsiak, hogy mekkora a teljes termelési hatása 3 Ft-nyi végsőkereslet-növekedésnek, akkor a multiplikátort egyszerüen meg kell szoroznunk 3-mal - ez is a linearitásnak köszönhető.

A multiplikátor nagysága mátrixalgebra segítségével határozható meg. Ha a technológiai együtthatók belső mátrixát kivonjuk az egységmátrixból, majd invertáljuk (ez a híres Leontief-inverz), akkor olyan termelési együtthatókat

1. ábra: Termelési multiplikátor: a végső felhasználás $1 \mathrm{Ft}$-os növekedésének hatása a bruttó kibocsátásra

Production multiplier: the effect of 1 HUF growth in final use on the gross output

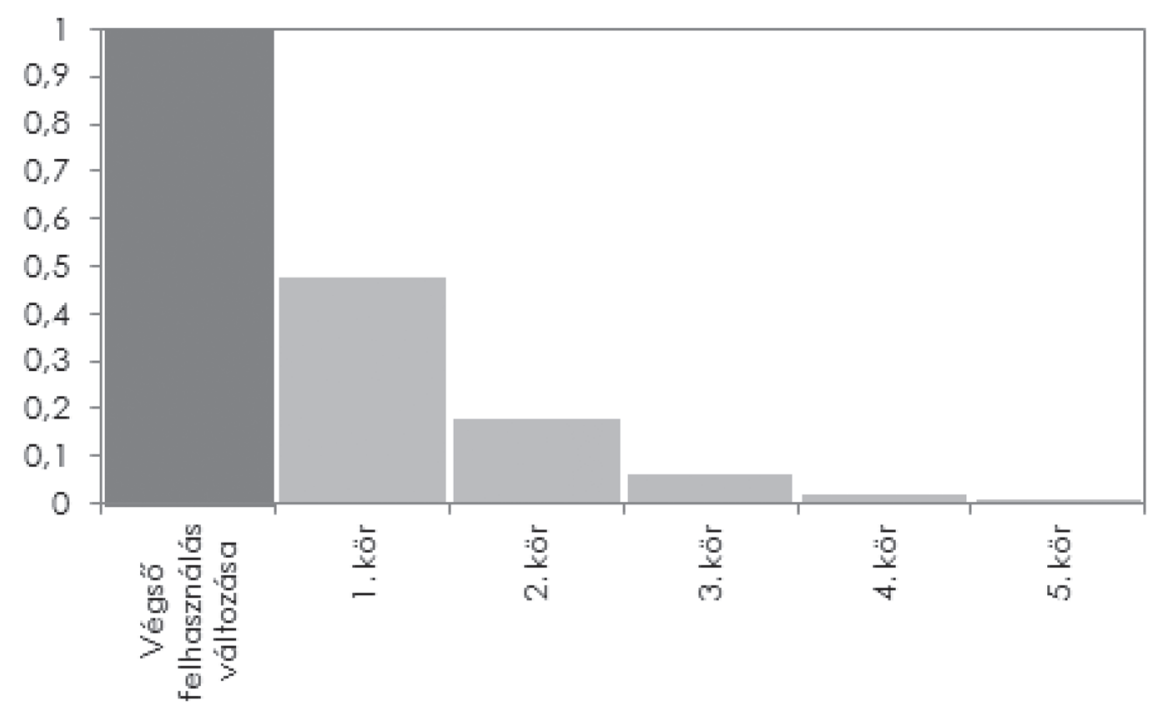


kapunk, amelyek nemcsak az 1. körös közvetlen, hanem 2., 3., 4. stb. körös közvetett hatásokat is magukban foglalják.

Multiplikátorokat nemcsak a bruttó kibocsátásra határozhatunk meg, hanem a hozzáadott értékre vagy annak bármely komponensére is. Szintén a linearitásból adódik, hogy a bruttó kibocsátás multiplikátorát egyszerüen meg kell szoroznunk az adott ágazati hozzáadott érték ráfordítási együtthatójával.

Felmerül a kérdés, hogy milyen időtáv kell a multiplikatív folyamat teljes megvalósulásához. Az input-output táblázat nem dinamikus, az idődimenziót nem kezeli. Az előrejelzett hatásokra általában rövid vagy középtávon számíthatunk, az alkalmazkodási idő ágazatonként eltérő lehet. A multiplikátorok által jósolt változások csak akkor következnek be, ha a figyelembe vett végső keresleti hatásokon kívül az alkalmazkodási folyamat során más sokkok nem érik a gazdaságot, s a technológiai összefüggések sem módosulnak.

\section{Jövedelemáramlási vagy társadalmi elszámolási mátrix}

Mi történik ezt követően a hozzáadott érték részeként keletkező jövedelmekkel? A munkavállalók béreik után munkavállalói járulékokat és adókat fizetnek, a vállalati eredmény egy részét visszaforgatják, másik részét kifizetik a tulajdonosok számára, ezt ugyancsak adók, járulékok terhelik. Az állam az összegyüjtött bevételekből egyrészt finanszírozza müködését, fogyasztását és beruházásait, másrészt transzferek formájában másodlagos jövedelmeket juttat a gazdaság többi szereplőjének. A háztartások a rendelkezésre álló jövedelmükből fogyasztanak, a vállalati szektor beruházásokat valósít meg.

A jövedelmek szektorok közötti áramlását, újraelosztását és végső keresletté való átalakulását foglalja rendszerbe a jövedelemáramlási vagy más néven társadalmi elszámolási mátrix (social accounting matrix, SAM), amelynek egy leegyszerűsített változatát mutatja Godley, Lavoie (2012) nyomán az 1. táblázat.

1. táblázat: Jövedelemáramlási vagy társadalmi elszámolási mátrix Social accounting matrix

\begin{tabular}{lcccc|c}
\hline & Háztartások & \multicolumn{2}{c|}{ Vállalatok } & \multirow{2}{*}{ Kormányzat } & $\Sigma$ \\
\cline { 3 - 4 } & & Folyótételek & Tóketételek & & \\
\hline Fogyasztás & $-\mathrm{C}$ & $+\mathrm{C}$ & & & 0 \\
Kormányzati kiadások & & $+\mathrm{G}$ & & $-\mathrm{G}$ & 0 \\
Magánberuházások & & $+\mathrm{I}$ & $-\mathrm{I}$ & & 0 \\
Bérek & $+\mathrm{W}$ & $-\mathrm{W}$ & & & 0 \\
Profit & $+\mathrm{DP}$ & $-\mathrm{DP}$ & & & 0 \\
Nettóadó́k & $-\mathrm{T}$ & & & $+\mathrm{T}$ & 0 \\
\hline$\Sigma$ & $\mathrm{S}_{\mathrm{H}}$ & 0 & $-\mathrm{I}$ & $\mathrm{PB}$ & 0 \\
\hline
\end{tabular}

Forrás: Godley, Lavoie 2012, 5. 
A társadalmi elszámolási mátrix az input-output táblához hasonlóan szigorú könyvelési logikán alapuló, konzisztens rendszer. Soraiban a jövedelmek és kiadások különböző típusai, oszlopaiban pedig az egyes makrogazdasági szereplők be- és kiáramló tételei láthatók. A háztartások a vállalatoktól bért (wages, W) kapnak, amely a cégeknél negatív, a háztartásoknál pozitív előjellel jelenik meg. A vállalatok tulajdonosai profitot realizálnak, ez a tétel is negatív előjellel szerepel a vállalati szektornál és pozitívval a háztartásoknál. Tegyük fel, hogy a vállalati nyereséget osztalék, részesedés formájában teljes egészében kifizetik (distributed profits, DP). Példánkban csak a háztartási szektor fizet adót (tax, T), amely nála negatív, a kormányzatnál pozitív előjellel jelentkezik. A háztartások fogyasztási (consumption) és a kormányzat (government) kiadásai $(-C,-G)$ a vállalatokhoz áramolnak $(+C,+G)$, a vállalatok beruházási (investments) kiadásai (-I) pedig más vállalatokhoz (+I).

A kettős könyvelés miatt a táblázat sorainak összege nullát ad: minden tétel, minden áramlás jön valahonnan és megérkezik valahová. A táblázat oszloponkénti összegei a szereplők finanszírozási igényét vagy képességét adják. Feltételezéseinknek köszönhetően a cégek folyó bevételei és kiadásai megegyeznek egymással, a vállalati finanszírozási igény teljes egészében a tőkeállomány bővítését szolgálja. Ezt és a költségvetés esetleges hiányát, negatív elsődleges egyenlegét (primary balance, PB) finanszírozza a háztartási szektor megtakarítása, amely nem más, mint a háromszektoros makrogazdaság jól ismert, tankönyvi egyensúlyi feltétele.

Az 1. táblázatban bemutatott mátrix az alkalmazott feltevések feloldásával, a jövedelem- és kiadástípusok megkülönböztetésével bonyolult rendszerré nőheti ki magát. A szektorok közé beépíthetjük a pénzügyi közvetítőrendszert, a sorok közé pedig a különböző vagyoneszközöket is. ${ }^{2}$ Így a mátrix már nemcsak a jövedelemtermelés és -elosztás, hanem a vagyoneszközök változásainak stock-flow-konzisztens elszámolótáblájává is válik. Ebben az esetben az oszlopösszegek is nullát adnak.

A társadalmi elszámolási mátrix sorai és oszlopai kizárólag könyvelési összefüggéseket, mindenkor érvényesülő azonosságokat adnak meg, semmit sem mondanak a szereplők magatartását meghatározó tényezőkről. A mátrix csupán egy csontváz, amelyet magatartási egyenletek segítségével életre kell kelteni.

\section{A keynesi kiadási-jövedelmi multiplikátor}

A legegyszerübb megoldás, ha a háztartások fogyasztását - a keynesi recept szerint konstans fogyasztási határhajlandóságot feltételezve - a rendelkezésre álló jövedelem lineáris függvényévé tesszük. Ekkor a külgazdasági kapcsolatok nélküli zárt, kétszektoros gazdaságban a hozzáadott érték (yield, Y) teljes egészében a háztartási szektorhoz áramlik (feltételezve, hogy az összes vállalati jövedelmet kiosztják, valamint hogy az értékcsökkenés nulla), amely minden pótlólagos jövedelemegység ĉ hányadát költi fogyasztásra. 
Ahogyan azt az input-output modellben is láttuk, a növekvő végső fogyasztás többlettermelést, $s$ ezáltal pótlólagos jövedelmeket generál. Ez a multiplikatív folyamat nem azonos az input-output modellben bemutatott, termelő felhasználáson keresztül megvalósuló megtöbbszöröződéssel. A keynesi kiadási multiplikátor a GDP-re vonatkozik, a termelő felhasználás változását figyelmen kívül hagyja. A hozzáadott érték megegyezik a végső felhasználásra kerülő termékek és szolgáltatások értékével. Így ha a végső kiadások 1 egységgel bővülnek, s a vállalati szektor a megnövekedett keresletet képes kielégíteni, akkor a GDP, s ezáltal a háztartási jövedelem is ugyanennyivel növekszik. 1 egységnyi jövedelemnövekmény a fogyasztási keresletet $\hat{c}$ egységgel növeli, ami $\hat{c}$ jövedelemnövekményt és $\hat{c}^{2}$ fogyasztásnövekményt generál a következö körben. A multiplikátor az $1, \hat{c}, \hat{c}^{2}, \hat{c}^{3}, \ldots$ végtelen mértani sorozat elemeinek az összege, amely a jól ismert $1 /(1-\hat{c})$ formulával határozható meg (lásd a 2. ábra jobb felső képletét, ahol $\Delta \mathrm{E}_{0}$ az autonóm kiadások, $\Delta Y^{e}$ pedig az egyensúlyi GDP változását jelöli). Mivel a fogyasztási határhajlandóság jellemzően 0-nál nagyobb és 1-nél kisebb, a multiplikátor értéke meghaladja az 1-et. Ha a fogyasztási határhajlandóság például 0,75, akkor a multiplikátor 4 , vagyis a végső kiadások egyégnyi változása 4 egységgel módosítja az egyensúlyi GDP-t. Mindez az ábrán is jól nyomon követhető: ha a kiadások (E) emelkednek, azaz a makrokeresleti függvény felfelé tolódik (E'), akkor a multiplikáció következtében az egyensúlyi GDP $\left(\mathrm{Y}^{\mathrm{e}}\right)$ a kezdeti kiadásváltozásnál nagyobb mértékben emelkedik ( $\left.\mathrm{Y}^{\mathrm{e}}\right)$.

A keynesi kiadási-jövedelmi multiplikátornak nemcsak ez az egyszerü változata használatos. A 2. ábra melletti alsó képlet egy nyitott gazdaságra vonatkozó formula, ahol $\mathrm{m}$ az importhányadot, $\mathrm{t}$ az átlagos adókulcsot, g pedig a

2. ábra: A keynesi kiadási-jövedelmi multiplikátor The Keynesian multiplier

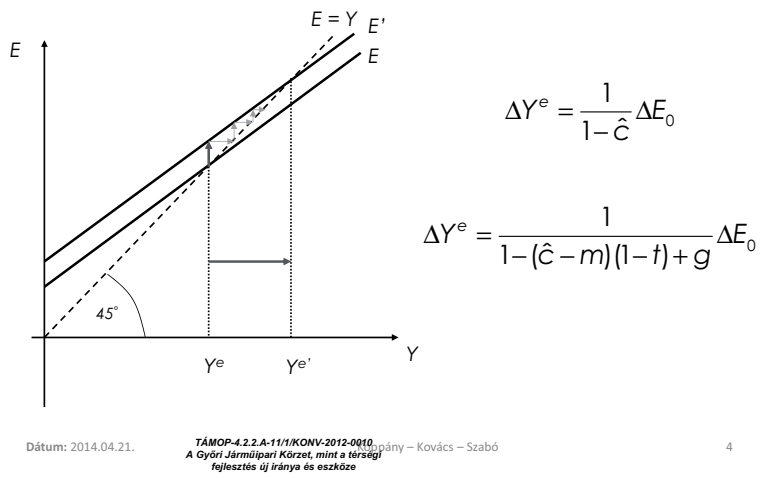

Forrás: Farkas, Koppány 2006, 314. 
kormányzat GDP-re vonatkozó kiadási hajlandóságát jelöli. Ebben a valósághoz jobban közelítő esetben már nem feltétlenül kapunk 1 feletti multiplikátort.

\section{A termelési és a jövedelmi multiplikátor összekapcsolása}

Mivel a korábban bemutatott input-output elemzés nem veszi figyelembe a jövedelemnövekedés keresletteremtő hatását, a keynesi kiadási multiplikátor pedig nem számol a termelő felhasználás és a bruttó kibocsátás bővülésével, célszerű a két mechanizmus összekapcsolása. Erre két lehetőség is kínálkozik (3. ábra).

Az egyszerűbb megoldás az input-output táblában a belső négyzet bővítése a háztartási jövedelem sorával és a háztartási felhasználás oszlopával, majd ennek invertálása. Az így kapott multiplikátorok a kiadási-jövedelmi hatásokat is magukba foglalják.

A másik lehetőség az input-output tábla és a társadalmi elszámolási mátrix összekapcsolása, amelynek során az ágazati kapcsolati mérleg alsó szárnyának tényezőjövedelmeit becsatornázzuk a jövedelemáramlási mátrixba, ott végrehajtjuk a gazdaságra jellemző paramétereknek megfelelő jövedelemelosztást és újraelosztást, majd a rendelkezésre álló jövedelmekből megvalósuló, ugyancsak a gazdasági sajátosságokhoz illeszkedő magatartási egyenletek szerinti végső kiadásokat visszavezetjük az input-output tábla oldalszárnyába.

Az input-output elemzés és a társadalmi elszámolási mátrix összekapcsolása így egy zárt, sajátérték-egyenletrendszerrel meghatározott, általános egyensúlyi modellt eredményez, amely minden lényeges gazdasági jelenséget bevon a körkörös kapcsolatok rendszerébe (Zalai 2000).

\section{3. ábra: Az input-output elemzés és a jövedelemáramlási mátrix összekapcsolása Linking the input-output analysis and the social accounting matrix}

\section{Input-output tábla}

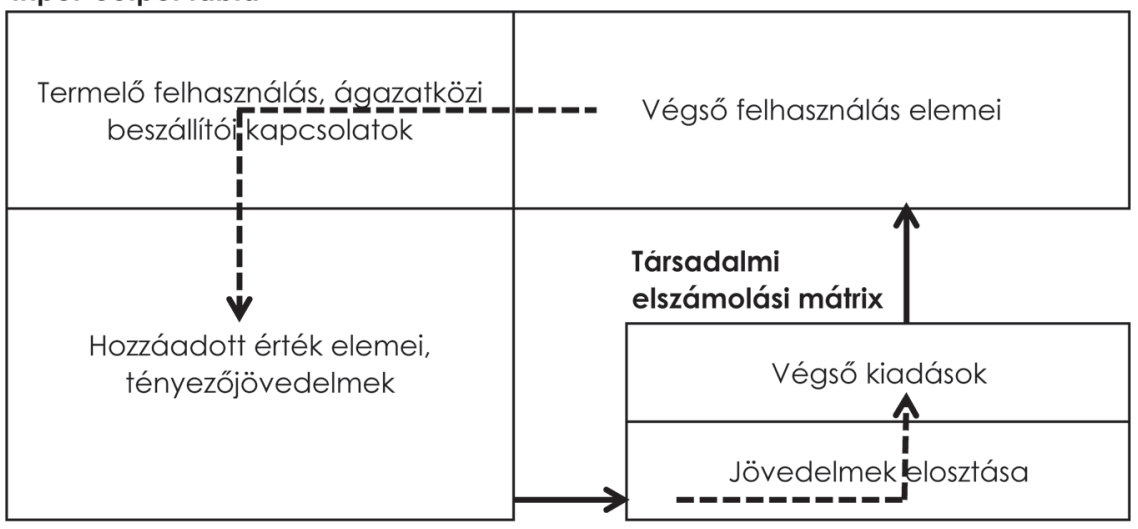




\section{Regionális alkalmazások}

Az előző részben bemutatott modellek, modellelemek mindegyike alkalmas regionális elemzésekre is. A következőkben ezekre mutatunk néhány példát.

\section{Regionális input-output modellek}

Az input-output modellt leggyakrabban kétségkívül a nemzetgazdasági termelési rendszerek elemzésére alkalmazzák, de használható nagyobb vagy kisebb gazdasági egységekre is.

Az ágazati kapcsolatok mérlege többféleképpen állítható össze. Egyrészt a területi elv, másrészt az ágazati elv, harmadrészt pedig a két elv együttes figyelembevételével. A területi és ágazati elv együttes érvényesítése az egy földrajzi térben lévő gazdasági ágazatok közötti kapcsolatrendszer elemzését a földrajzi tér határain keresztüli áramlások ágazatonkénti elemzésével egészíti ki. Ez teszi lehetővé a területek közötti kapcsolatok elemzését, a területközi áramlások ágazatonkénti bontásban történő vizsgálatát. A regionális input-output modellel egy régió vagy a régió egy adott ágazatának termékei iránti pótlólagos kereslet multiplikatív hatásait elemezhetjük (Rechnitzer 1984).

Regionális input-output modelleket először az 1950-es és 1960-as években alkalmaztak, de kísérletek történtek interregionális és multiregionális inputoutput modellek kidolgozására is. Az interregionális és multiregionális inputoutput modellek összeállítása nagy mennyiségü, nehezen összegyüjthető adatot igényel, így sok példát sem hazánkban, sem más országokban nem találunk az alkalmazásukra (Lengyel, Rechnitzer 2004).

A nemzetgazdasági szintű input-output modelleket regionális és városi gazdasági rendszerek elemzésére használva kiderült, hogy azokat az eltérő sajátosságok miatt módosítani kell. Miller és Blair (2009) szerint két olyan speciális tulajdonságot hordoz a regionális dimenzió, amely egyértelművé és szükségessé teszi a makrogazdasági modellektől való megkülönböztetést.

Az első, hogy minden régiónak speciális termelési szerkezete van, amely megkülönbözteti a többitől és az általános makrogazdasági szerkezettől. Egy régió vagy más földrajzi egység lehet zárt vagy nyitott. Az adott földrajzi térben jelen lévő ipar tradíciói, az oktatás minősége, az adott térben rendelkezésre álló erőforrások, az adott régió termelési technológiája lényegesen különbözhet, s elképzelhető, hogy a helyi kibocsátás felhasználása is jelentős részben a földrajzi területen belül valósul meg. Más régiók ugyanakkor sokkal inkább kitettek a külső gazdasági kapcsolatoknak, s az adott térben jelen lévő kereslet és kínálat elemei jelentős részben az adott régió földrajzi határain kívülről származnak.

A második, hogy minél kisebb a vizsgálat tárgyát képező gazdaság, általában annál inkább függ a külső gazdaságtól (a többi anyaországi és külföldi 
régiótól), s ez azt jelenti, hogy az export- és az importparaméterek értéke emelkedik a regionális modellekben.

1950-es évekbeli megjelenésüket követően a regionális input-output modellek folyamatosan fejlődtek. Ennek mozgatórugóit Sargento (2009) szerint elsősorban a következő tényezők jelentették.

1. A modell által kezelhető régiók száma, amely alapján megkülönböztetjük az egyrégiós input-output modellt a többitől. Az egyrégiós modell kizárólag az intraregionális hatásokat ragadja meg, a többi régióval való kapcsolatokat, ezek hatását az áramlásokra nem veszi figyelembe vagy minimalizálja. A valóságban ha egy régióban növekszik a termelés, akkor számos változás következik be a végső keresletben. Így például ha a termelés növekedése nagyobb alapanyag-felhasználással jár, amelyet a szomszédos régióból importálnak, akkor az emelkedő kibocsátás növekvő termelési volument eredményez a szomszédos régióban is, s ennek számos tovagyürüző hatása van az adott régión belül és annak határain túl egyaránt.

2. Az interregionális kapcsolatok felismerését és a modellalkotásban történő figyelembevételét éppen az egyrégiós modellek általánosíthatóságának hiánya eredményezte. Szükségessé vált az interregionális visszacsatolások beépítése; egyrészt azoké, amelyek a fejlődő régiórészre hatnak, másrészt pedig azoké, amelyek a régió többi részére (például a város vonzáskörzetére) (Miller 1998). Több régió kapcsolatrendszerének input-output modellekben való figyelembevételét Walter Isard dolgozta ki (Glasmeier 2004).

3. A gyakorlati alkalmazások nehézségei, így a müködtetésükhöz szükséges interregionális kereskedelmi adatok összegyüjtésének nehézségei hívták életre a többrégiós modelleket.

4. A fejlődés során folyamatosan változtak a kereskedelmi koefficiensek becslésekor alkalmazott feltevések.

A multiregionális modellek közötti különbséget alapvetően a 3. és a 4. pontban meghatározott tényezők okozzák.

Nézzünk ezek után néhány konkrét alkalmazást!

Leontief első, mind matematikai apparátusát, mind adatigényét tekintve egyszerü városi input-output modelljét 1953-ban készítette. Későbbi nemzetközi modelljében, amelyet gyakran egyensúlyi regionális modellnek neveznek, tudatosan jelenítette meg azt a megfigyelését, hogy bizonyos jószágok termelési helye közel van a fogyasztási helyeikhez, míg mások esetében jelentősek a szállítási távolságok (idézi Sargento 2009). Ezért Leontief két jószágtípust különböztetett meg: a regionálist és a nemzetit. A regionális jószágokat ugyanazon régióban termelik és fogyasztják el, ilyenek például a helyi szolgáltatások vagy az ingatlanok. Ezzel szemben a nemzeti javak könnyen vagy könnyebben szállíthatók, s ezek termelési-fogyasztási egyensúlya nemzeti vagy nemzetközi szinten valósul meg. Ilyenek például az autók vagy a ruházati termékek. Az előzőekből kifolyólag vannak olyan régiók, amelyek inkább exportálnak, s vannak 
olyanok is, amelyek importálnak. A modell nettó kereskedelmi áramokat számít, nem határozza meg az import és az export eredetét és rendeltetési helyét. Ez az oka, hogy Leontief modelljét sokkal inkább az intraregionális, mintsem az interregionális gazdasági kapcsolatrendszer és fejlődés modellezésére használják a gyakorlatban (Miller, Blair 2009).

Isard (1951) az interregionális kapcsolatok modellezésére törekedett. Miller (1998) példájában az Isard-féle koncepció kétrégiós esetét láthatjuk. Sajnos a modell adatigénye nehezen kielégítheto", ezért a gyakorlatban sokkal elterjedtebb a Chenery-Moses-féle módosított többrégiós változat. Chenery (1953) és Moses (1955) azzal az egyszerüsítéssel éltek, hogy a kereskedelmi áramlásokból kihagyták az iparági szintet, csak a származási régió és a felhasználási régió játszik szerepet. Ez csökkentette a modell adatigényét, így a kutatók könnyebben tudták számszerüsíteni a kapcsolatokat.

Riefler és Tiebout (1970) kétrégiós modellje szintén a fontosabb típusok közé tartozik. A két régió kapcsolatrendszere mellett a külső, világgazdasági kapcsolatok is megjelennek az export- és az importmátrixban. Az adatokat tekintve több, felmérésen alapuló információt igényel, mint a Chenery-Moses-modell. Riefler és Tiebout Kalifornia és Washington példáján empirikusan is kipróbálták a modellt, amelyben Washingtonra készítettek import- és exportmátrixot. Minden termelo" és végső fogyasztó szektorra meghatározták, hogy az input hány százaléka érkezik külföldről, illetve távozik külföldre. A legnagyobb gyakorlati problémát az import és az export kaliforniai és nem kaliforniai részre való felosztása jelentette (Harrigan, McGilvray, McNicoll 1981). A modellben a szerkezetet leíró egyenletek nagyon hasonlóak, mint az Isard-féle modellben.

A nemzetközi alkalmazásokra további példa Carlberg (1978) regionális növekedési modellje. Carlberg a Német Szövetségi Köztársaság tartományainak inputoutput táblázatait állította össze az 1960-as, 1970-es évekre. Hipotézise szerint a nagyobb népességü tartományok termelési technológiája jobban hasonlít a nemzetihez, állítását egy multiregionális input-output modell segítségével igazolta. Megemlíthetjük még McNicoll modelljeit, amelyekkel az északi-tengeri olaj és a turizmus multiplikatív hatását elemezte a Shetland-szigetek és a Külső Hebridák esetében (Armstrong, Taylor 2000).

Máig az egyik legjelentősebb és legszélesebb körben használt regionális input-output modell az 1970-es évek elején az Egyesült Államokra kidolgozott, azóta folyamatosan fejlesztett és aktualizált RIMS II (Regional Input-Output Modelling System). A Bureau of Economic Analysis (BEA) és a U. S. Department of Commerce által gondozott modellt üzleti célú magánberuházók, szövetségi, állami és helyi kormányzati döntéshozók, regionális fejlesztők sora használja hatástanulmányok készítéséhez. Az input-output elemzésben megszokott módon a RIMS II az idődimenziót nem kezeli, állandó skálahozadékot, homogén és rögzített iparági struktúrát, valamint tökéletes kínálatoldali alkalmazkodást feltételez. A helyi kínálati feltételeket a nemzeti input-output táblából kiindulva az iparág regionális koncentrációjának nemzeti koncentrációhoz viszonyí- 
tott aránya alapján határozza meg. A RIMS II egyrégiós modell, a régiók közötti visszacsatolásokat nem veszi figyelembe (Ambargis, Mead 2012).

A hazai regionális modellek közül a legismertebb a Csepinszky, Kovács, Novák szerzőhármas által Vas megyére kidolgozott mérleg, valamint a Fodor, Illés, Bognárné-féle, központi körzetre vonatkozó modell (Smahó 2007). Rechnitzer János mérlege Baranya megye gazdasági ágazati kapcsolatait tárja fel. Célja a térségek, régiók terveinek, fejlesztési elképzeléseinek kidolgozása és összehangolása, a fejlesztések következményeinek meghatározása volt (Rechnitzer 1984).

A regionális input-output modellek alkalmazásánál nem szabad figyelmen kívül hagyni az elméleti és a modellépítésből fakadó korlátokat. Az első az adatigény, amely a primer és szekunder adatgyűjtés nehézségeivel és költségeivel jár együtt. A második az adatfeldolgozás. Az adatkorlátok szempontjából a kisméretü, zárt regionális gazdaságokra épített input-output modellek könnyebben alkalmazhatók (Richardson 1973). Lényeges és a gyakorlati alkalmazásokban gyakori, hogy a nemzeti technológiai mátrixot alkalmazzák adatbázisként, éppen a kisebb területi egységek adathiánya okán. A termelési technológia, a skálahozadék, az importfüggőség és az exportvolumen azonban régiónként eltérő és nagyban különbözhet a nemzetitől (Armstrong, Taylor 2000), ezért a probléma kezelésére különféle közelítő módszereket dolgoztak ki (Sargento 2009).

Mindezek a korlátok esetünkben bizonyos szempontból fokozottan jelentkeznek, feloldásukra azonban eddigi kutatásainkban nem vállalkozhattunk. Két út közül választhattunk. Az egyik, hogy függetlenítjük magunkat a gazdasági rendszer alapösszefüggéseitől, s azokból az adatokból próbálunk meg modellt alkotni, amelyek rendelkezésünkre állnak. Ezek között statisztikai összefüggéseket keresünk, s a feltárt kapcsolatokra alapozva gazdasági előrejelzéseket adunk (lásd Smahó 2007). A másik út, hogy egy logikailag zárt, a gazdaság egészének működését leíró elméleti keretet állítunk fel, majd ezt próbáljuk meg adatokkal feltölteni, még ha bizonyos pontokon ez nehézségekbe is ütközik. Mi ez utóbbit választottuk.

A továbbiakban kétrégiós input-output táblát alkalmazunk. A 2. táblázat modelljében a város szerepét az egyik, a vonzáskörzetét pedig a másik régió tölti be. Így értelmezhetők a városon belüli, a vonzáskörzeten belüli, a város és a vonzáskörzet közötti relációk, valamint a város és a vonzáskörzet külső régiókkal való kapcsolatai is.

\section{Regionális termelési multiplikátorok}

A regionális input-output táblákból a korábban megismert mátrixműveletekkel származtathatjuk a regionális termelési multiplikátorokat. Ezek a modell legfontosabb, a gazdasági hatáselemzések során közvetlenül felhasználható kimenetei. A RIMS II felhasználói csak ezekhez az ágazatokra és területi egységekre meghatározott multiplikátorokhoz férhetnek hozzá táblázatgyüjteményekben 


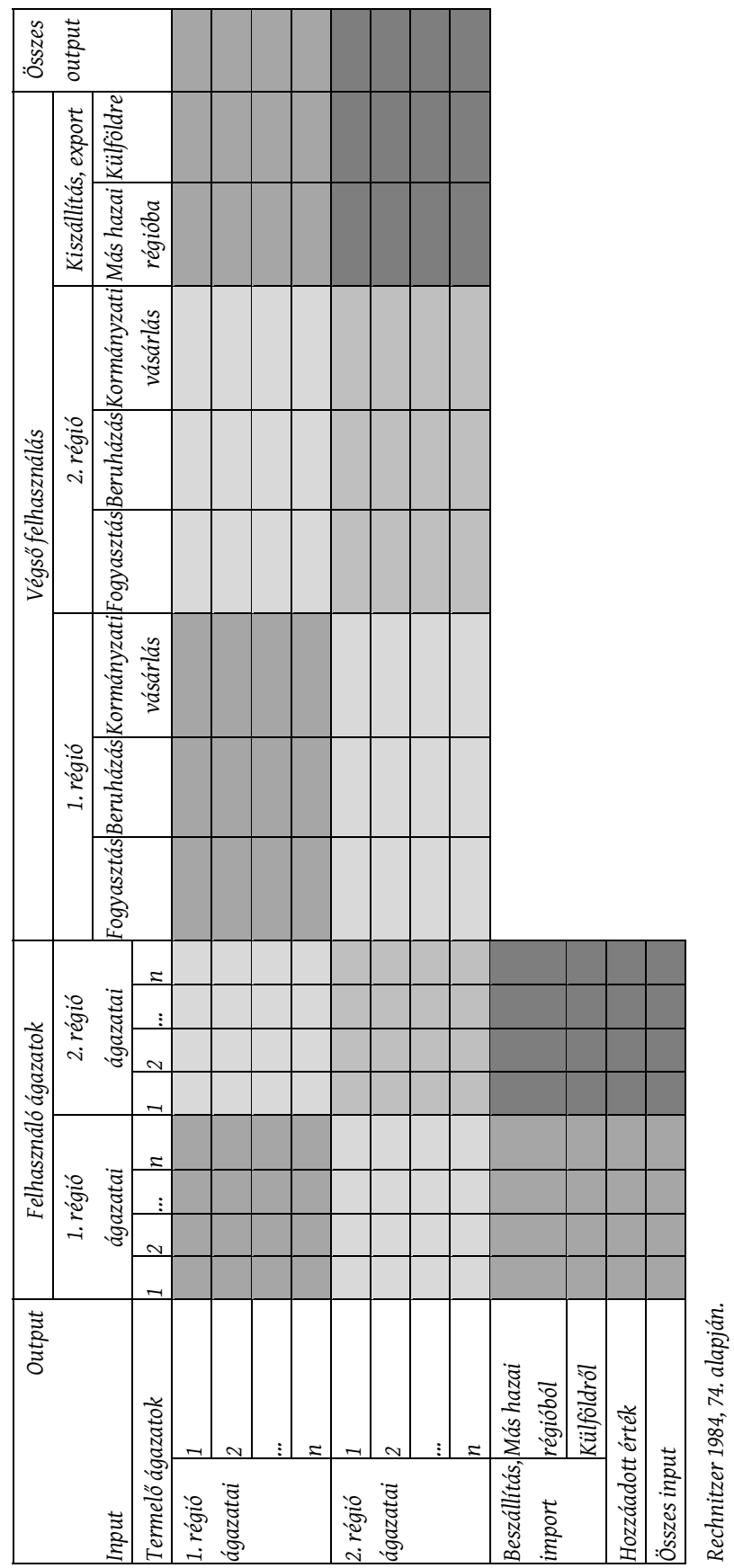


(Daley, Ehrlich, Landefeld, Barker 1997). A táblázatok a bruttó kibocsátásra, a hozzáadott értékre, a háztartási jövedelmekre és a foglalkoztatásra vonatkozó multiplikátorokat tartalmazzák. Ezek a végső keresletben adott ágazatban és adott régióban bekövetkező 1 egységnyi változás hatását fejezik ki a régió össztermelésére, GDP-jére, lakossági jövedelmeire és foglalkoztatására.

A végső keresleti multiplikátorokon kívül a RIMS II úgynevezett direkt multiplikátorokat is megad. Kétféle direkt multiplikátorral találkozhatunk. A jövedelmi multiplikátor azt mutatja meg, hogy 1 egységnyi jövedelemnövekedés valamely régió valamely ágazatában hány egységgel növeli a régió lakosságának összjövedelmét. A foglalkoztatási direkt multiplikátor pedig azt fejezi ki, hogy ha az adott régió adott ágazatában 1 fövel változik az alkalmazottak száma, akkor ez - a tovagyürűző hatásokat figyelembe véve - összességében hány fővel változtatja a régió foglalkoztatását. Hasonló elven számított mutatószámokat közöl Fodor és Illés (1968).

\section{Regionális társadalmi elszámolási mátrixok}

Regionális társadalmi elszámolási mátrixok alkalmazására a hazai szakirodalomban egyáltalán nem találtunk példát, a nemzetköziben is csak néhányat. A tanulmányok nagy része mezőgazdasági kutatóintézetekben készült. Bussolo, Chemingui és O'Connor (2003) India multiregionális társadalmi elszámolási mátrixát és regionális, környezeti általános egyensúlyi modelljét fejlesztette ki. Punt, Pauw, van Schoor, Gilimani, Rantho, McDonald és Chant (2006) Dél-Afrikára építettek nemzeti, multiregionális és regionális társadalmi elszámolási mátrixokat. Kuhar, Golmenova, Erjavec, Kožar és Cör (2009) a társadalmi elszámolási mátrix regionalizálásáról írnak. Új-Zélandon Martana, Evison, Lennox és Manley (2012) egy nem kérdőíves módszerrel összeállított regionális társadalmi elszámolási mátrixot mutatnak be, amelyet általános egyensúlyi elemzés céljából hoztak létre.

E modellek logikai elve megegyezik az 1. táblázatban bemutatott Godley-Lavoieféle általános nemzeti jövedelemáramlási mátrixszal. A különbség csupán az, hogy kisebb területi egységre vagy egységekre vonatkoznak, s esetenként több régió kapcsolatait, egymás közötti áramlásait, elszámolásait is mutatják. Godley és Lavoie (2012, 172.) is közöl egy kétrégiós gazdaságra felírt táblázatot.

A 3. táblázatban bemutatott saját fejlesztésű mátrixunk több ponton is eltér Godley és Lavoie regionális modelljétől. Bizonyos szempontból egyszerűbb: nem tartalmazza a vagyoneszközök állományváltozásait és a központi bankot. Más szempontból viszont jóval összetettebb: nemcsak a termelő felhasználás, hanem a végső kiadások és a jövedelmek régiók közötti áramlásait is figyelembe veszi. A későbbiekben ebből kiindulva jutunk el modellünk egyik fontos szerkezeti egységéhez, a város és vonzáskörzetének jövedelem- és kiadásáramlásait magába foglaló társadalmi elszámolási mátrixhoz. 
A 3. táblázat egyelőre teljesen általános regionális megközelítést tükröz, ahol a vizsgált földrajzi tér egyik régióját belső gazdaságnak, másik régióját külső gazdaságnak nevezzük. A modell zárt gazdaságot feltételez, a központi kormányzaton kívül a két régiónak kizárólag egymással vannak gazdasági kapcsolatai. A belső gazdaságból kiinduló áramlásokat i alsó indexszel, a külső gazdaságból kiindulókat pedig e alsó indexszel jelöljük. Ha az i és e betűk nem alsó indexként jelennek meg, hanem éppen ezeket látjuk el alsó indexekkel, akkor i és e az alsó indexben jelzett jövedelmeknek és kiadásoknak a helyben, vagyis a belső, illetve a külső gazdaságban maradó hányadait jelölik.

A belső és a külső gazdaság vállalatai egyaránt fizetnek munka- $\left(W_{i}, W_{e}\right)$ és tőkejövedelmeket ( $\mathrm{DP}_{\mathrm{i}}, \mathrm{DP}$ ), ezek azonban csak részben maradnak a keletkezési régióban. A belső gazdaság háztartásaihoz a belső vállalatok bérkifizetéseinek $\mathrm{i}_{\mathrm{w}}$, a külső vállalati béreknek pedig $\left(1-\mathrm{e}_{\mathrm{w}}\right)$ hányada áramlik. A tőkejövedelmek esetében $\mathrm{i}_{\mathrm{DP}}$, illetve $\left(1-\mathrm{e}_{\mathrm{DP}}\right)$ arányokkal kell számolnunk. A külső gazdaság háztartásaihoz értelemszerüen $\mathrm{e}_{\mathrm{w}} \times \mathrm{W}_{\mathrm{e}}+\left(1-\mathrm{i}_{\mathrm{w}}\right) \mathrm{W}_{\mathrm{i}}$ bér- és $\mathrm{e}_{\mathrm{DP}} \times \mathrm{DP}_{\mathrm{w}}+\left(1-\mathrm{i}_{\mathrm{DP}}\right) \mathrm{DP}$ tőkejövedelem kerül.

Jelenlegi modellünkben kizárólag a háztartások fizetnek adókat. Ezek egy része helyi (local tax, $\mathrm{LT}$ ), másik része központi (central tax, $\mathrm{CT}$ ).

Régiók közötti áramlás nemcsak a jövedelmekben, hanem a kiadásokban is van. A belső gazdaság háztartásainak fogyasztási kiadásai $\left(C_{i}\right)$ csak $i_{C}$ részben áramlanak helyi, belső gazdaságbeli vállalatokhoz, $\left(1-i_{C}\right)$ hányaduk a periféria cégeinél jelentkezik. Ugyanez a helyzet a külső gazdaság végső fogyasztási kiadásaival $\left(\mathrm{C}_{\mathrm{e}}\right)$, amelyek helyben maradó hányada $\mathrm{e}_{\mathrm{C}}$, a fennmaradó $\left(1-\mathrm{e}_{\mathrm{C}}\right)$ hányad a centrum vállalatainál jelent bevételt.

Hasonló elvek szerint bontjuk a beruházási és a helyi kormányzati kiadásokat. A vizsgált térség vállalatainál jelentkező állami megrendelések a központi kormányzattól is származhatnak (central government, CG), amelyből $C^{\mathrm{i}}{ }^{\mathrm{i}}$ jelenti a belső régió, $C G^{e}$ pedig a külső régió vállalatainak kormányzati megrendeléseit.

A zárt gazdaságra vonatkozó társadalmi elszámolási mátrixtól eltérően a nyitott vagy többrégiós gazdaságot leíró mátrixban a termelő fogyasztás (intermediate consumption, IC) sorát is szerepeltetnünk kell, itt tüntetjük fel a régiók közötti beszállítások értékét. $\left(1-\mathrm{i}_{\mathrm{IC}}\right) \times \mathrm{IC} \mathrm{I}_{\mathrm{i}}$ a belső gazdaság tényezőfelhasználásának külső gazdaságból beszerzett részét, $\left(1-\mathrm{e}_{\mathrm{IC}}\right) \times \mathrm{IC}_{\mathrm{e}}$ pedig a külső régió közbülső fogyasztásának belső gazdaságból származó részét jelöli. Előbbi a belső gazdaságban negatív, a külső gazdaságban pozitív előjelű áramlásként jelentkezik, utóbbi pont fordítva.

A táblázat utolsó sorában a finanszírozási pozíciók láthatók. $\mathrm{S}_{\mathrm{H}}^{\mathrm{i}}$ a centrum háztartásainak megtakarításait, $\mathrm{I}_{\mathrm{i}}$ a belső vállalatok beruházási finanszírozási igényeit, $\mathrm{S}_{\mathrm{LGi}}$ pedig a belső gazdaság helyi kormányzatának megtakarításait (vagy ellentétes előjellel hiányát - local budget deficit, $-\mathrm{LBD}_{\mathrm{i}}$ ) mutatja. Ugyanezeket a tételeket megtaláljuk a külső gazdaság szektoraira is, valamint látható a központi költségvetés régióhoz kapcsolódó tételeinek egyenlege. 

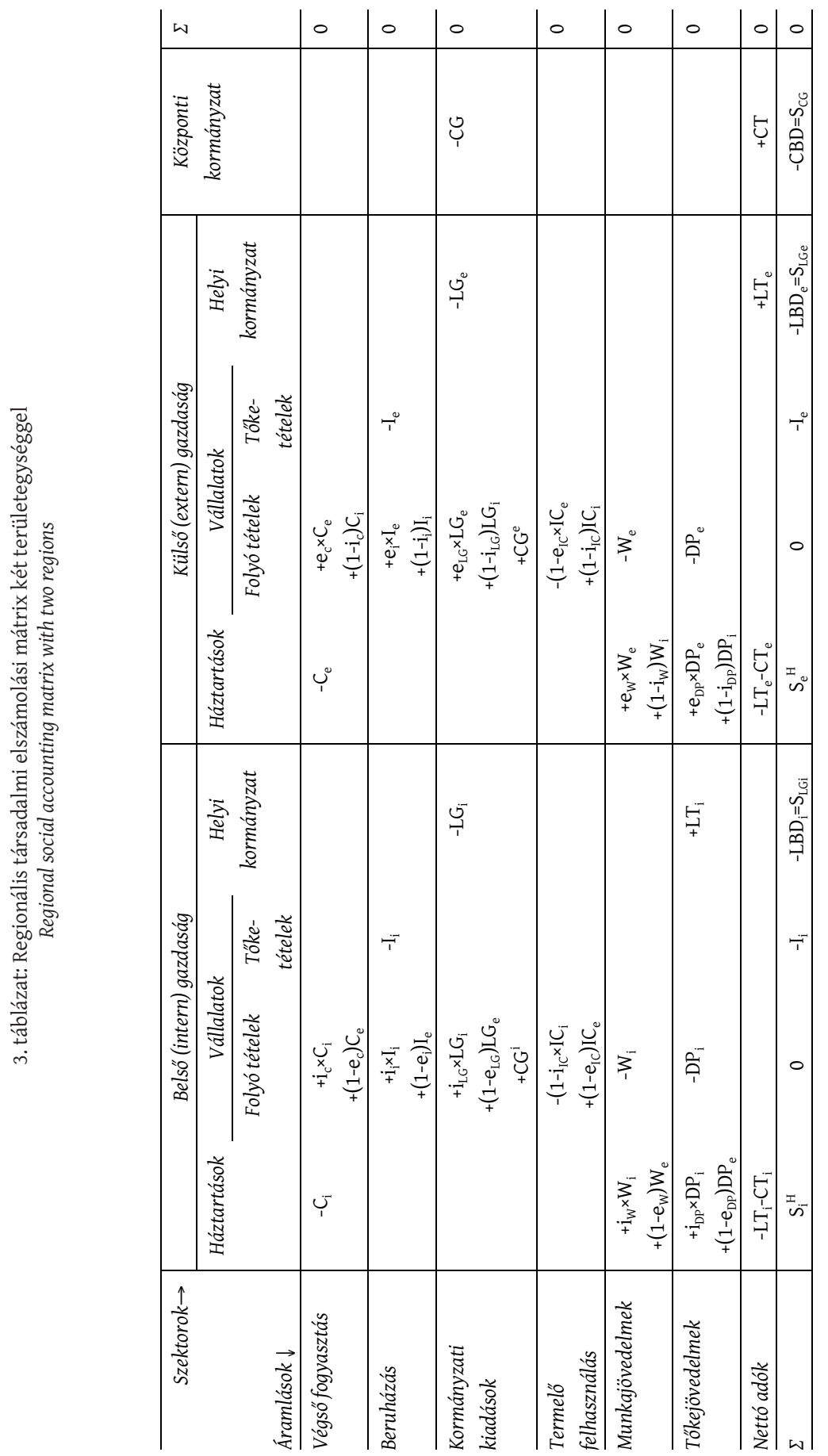


\section{Regionális kiadási-jövedelmi multiplikátorok}

A tanulmány előző, elméleti részében már bemutattuk a kiadási-jövedelmi multiplikáció folyamatát. A 2. ábrán szereplő alsó, összetett formula nemcsak nemzetgazdasági szinten, hanem kisebb területi egységekre is értelmezhető. Regionális alkalmazásakor azonban tudnunk kell, hogy ez a multiplikátor nem veszi figyelembe a régiók közötti kölcsönhatásokat. Az egyik régió importja ugyanis egy másik régió exportját jelenti. Amennyiben Y régióban növekszik az $\mathrm{X}$ régióból származó import, akkor ez a kereslet X outputja iránt multiplikátorhatással van $X$ régióban. Az ebből származó X-beli jövedelemnövekedés emeli X keresletét $Y$ exportja iránt, ezáltal Y kibocsátása és jövedelme is növekedni fog. Az X outputja iránti kezdeti keresletváltozásnak tehát visszacsatoló hatása van, $\mathrm{s}$ az egész körfolyamat addig folytatódik, amíg az addicionális jövedelem meg nem közelíti a nullát (Lengyel, Rechnitzer 2004).

A győri járműipari körzetre vonatkozó modellünk nem hagyhatja figyelmen kívül a város és vonzáskörzete közötti visszacsatolásokat, célunk pontosan ezen interdependenciák kimutatása. Az interregionális kölcsönhatások figyelembevételét szolgálja mind a 2. táblázat regionális input-output modellje, mind pedig a 3. táblázat regionális társadalmi elszámolási mátrixa. A kiadási-jövedelmi multiplikáció folyamatát is kétrégiós változatban, a régióközi visszahatásokat figyelembe véve kell értelmeznünk.

\section{A regionális termelési és jövedelmi multiplikátorok összekapcsolása}

A regionális input-output táblából számított elsődleges termelési multiplikátorok és a jövedelemváltozás által indukált, másodlagos kiadási multiplikátorhatások összekapcsolására a korábban már említett lehetőségek állnak rendelkezésünkre.

Az egyik a háztartási jövedelmek és fogyasztási kiadások regionális inputoutput táblában történő megjelenítése. Ezt a technikát alkalmazzák a RIMS II-ben is az ún. kettes típusú multiplikátorok számításakor.

Az input-output modellen belüli megoldás egyszerü és gyors, ugyanakkor pontatlanabb, mint az általunk javasolt összekapcsolás (3. ábra). Utóbbi megoldást valósítja meg az ugyancsak egyesült államokbeli fejlesztésű IMPLAN (Impact Analysis for Planning) modell. Az első verzió 1988-ban Minnesotában, az ottani egyetem mezőgazdasági tanszékén készült, kezdetben viszonylag szűk kutatói körben, elsősorban mező- és erdőgazdasági célokra használták. A nagy érdeklődésre való tekintettel a modellt több lépcsőben továbbfejlesztették. Az IMPLAN ma már - a RIMS II-höz hasonlóan - széles körben ismert és alkalmazott regionális tervező- és modellező eszköz. Az IMPLAN nem csupán multiplikátorokat közöl, hanem egy hatalmas regionális adatbázissal ellátott közgazdasági elemzőszoftver (implan.com). 


\section{Város és vonzáskörzete: a győri járműipari körzet alapmodelljének szerkezete}

A győri járműipari körzet alapmodelljének két legfőbb komponensét, az inputoutput táblát, a jövedelemáramlási mátrix paraméteres változatát, $\mathrm{s}$ ezek kapcsolatrendszerét mutatjuk be az alábbiakban.

Modellünk a város (Győr) és vonzáskörzete egymás közötti, valamint a régión (győri járműipari körzet) kívüli (más belföldi vagy külföldi) szereplőkkel folytatott tranzakcióihoz kapcsolódó áramlásait egyaránt kezeli. Tekintettel arra, hogy három áramlási irányt is figyelembe kell vennünk, korábbi jelölésrendszerünket kicsit módosítjuk. Az adott jövedelem vagy kiadás városban maradó vagy városba áramló hányadát i-vel, a vonzáskörzetben maradó vagy vonzáskörzetbe áramló hányadát e-vel, a más hazai régióba vagy külföldre áramló hányadát pedig m-mel jelöljük. Alsó indexben jelöljük azt a jövedelem- vagy kiadástípust, amelyre a hányadot vonatkoztatjuk. Értelemszerủen bármely jövedelemre és kiadásra igaz, hogy $\mathrm{i}+\mathrm{e}+\mathrm{m}=1$. Amennyiben i (belső gazdaság, város) vagy e (külső gazdaság, vonzáskörzet) betűk jelennek meg egy áramlás jelölésének alsó indexében, akkor az annak kiindulási vagy keletkezési helyére utal. Ha ugyanezek a betűk felső indexben szerepelnek, akkor ez az áramlás területi célpontját jelzi.

\section{A város és vonzáskörzetének input-output táblája}

A 4. táblázat a város és vonzáskörzete regionális input-output táblázata. A jobb felső részben látható belső mátrix a termelőegységek kapcsolatrendszerét képezi le. Jól látható, hogy a belső mátrix négy kisebb egységre tagozódik. A bal felső részmátrix termelő fogyasztásainál a város a beszállító és a város a felhasználó $\left(\mathrm{i}_{\mathrm{ICi}} \mathrm{IC} \mathrm{i}_{\mathrm{i}}\right)$, a jobb felsőben a város a beszállító és a vonzáskörzet a felhasználó $\left(\mathrm{i}_{\mathrm{ICe}} \mathrm{IC} \mathrm{e}_{\mathrm{e}}\right)$, a bal alsóban a vonzáskörzet a beszállító és a város a felhasználó $\left(\mathrm{e}_{\mathrm{ICi}} \mathrm{IC} \mathrm{C}_{\mathrm{i}}\right)$, a jobb alsóban pedig a vonzáskörzet vállalatai a vonzáskörzetbe szállítanak $\left(\mathrm{e}_{\mathrm{ICe}} \mathrm{IC}_{\mathrm{e}}\right) \mathrm{IC}_{\mathrm{i}}$ a városi, $\mathrm{IC}_{\mathrm{e}}$ pedig a vonzáskörzetbeli vállalatok termelő felhasználását jelöli.

A $2 n \times 2 n-e s$ belső mátrix alatt összesítjük a régión belüli felhasználásokat, majd az importigényeket vesszük sorra. A termelési célú importigények sora két részre osztható, az első a városi ágazatokba $\left(\mathrm{m}_{\mathrm{IC}} \mathrm{IC} \mathrm{C}_{\mathrm{i}}\right)$, a második a vonzáskörzet ágazataiba történő külső beszállításokat $\left(\mathrm{m}_{\mathrm{ICe}} \mathrm{IC}\right)$ mutatja. Import alatt nemcsak a külföldről, hanem minden, a városon és a vonzáskörzeten kívüli régióból történő behozatalt értjük.

Az alsó szárnyban szereplő hozzáadottérték-összetevőket város, vonzáskörzet, ezen belül ágazati bontásban kapjuk. Az alapmodellben ezeket (a termelő felhasználás tételeihez hasonlóan) területi elv szerint összesítve használjuk a társadalmi elszámolási mátrixban. A modell későbbi, továbbfejlesztett változataiban akár az ágazati bontást is megtarthatjuk, jelen esetben azonban az egyes jövedelemtípusoknál csupán város és vonzáskörzet megkülönböztetést teszünk. 
Adatgyüjtési okokból a vállalati $\left(\mathrm{WF}_{\mathrm{i}}, \mathrm{WF}_{\mathrm{e}}\right)$ és a kormányzati szféra munkajövedelmeit $\left(W L G_{i}, W L G\right)$ külön sorban tüntetjük fel. Az $F$ betűvel a vállalatokra (firms), G-vel a kormányzatra (government) utalunk. A WLG a város helyi (local, L) kormányzati szférájában keletkező munkajövedelmeit jelöli. Fontos, hogy helyi kormányzat alatt nemcsak a helyi önkormányzati működtetésủ fenntartású közintézményeket értjük, hanem minden, a városban GDP-t generáló állami intézményt. Például egy győri rendőr vagy egyetemi tanár bére éppúgy beletartozik WLG-be, mint egy önkormányzati alkalmazotté. A bérekhez hasonlóan azok járulékait is vállalati-kormányzati bontásban (TWF, TWLG) szerepeltetjük.

A városi és vonzáskörzetbeli ágazatok által fizetendő helyi és központi adókat nettó módon, a kapott támogatásokkal csökkentve vesszük figyelembe. A TLF (tax of local firms) a városi vállalatok helyi adóinak és a TRLF, helyi kormányzattól kapott transzfereinek (TR) különbségeként adódó nettó helyi adó. A központi adóknál L helyett C (central) betűket használunk. Látható, hogy a központi kormányzati transzfereknél az i és e betűk felső indexbe kerültek. Ezzel azt jelezzük, hogy a város (e), illetve a vonzáskörzet (i) nem a származási, hanem a célrégió. Hasonló jelöléssel találkozunk majd más, kívülről érkező áramlások esetén is.

Összevontan kezeljük a vállalkozásokba értékcsökkenés vagy mérleg szerinti eredmény formájában visszaforgatott tőkejövedelmeket (undistributed profits, UP). Az osztalék, részesedés formájában a tulajdonosoknak kiosztott vállalati eredményt a korábbiaknak megfelelően DP-vel (distributed profits) jelöljük.

A jövedelemelemek összesítésével megkapjuk területi hozzáadott értékeket $\left(\mathrm{Y}_{\mathrm{i}}, \mathrm{Y}_{\mathrm{e}}\right)$, valamint a hozzáadott értékek és a tényezőfelhasználások összegeként a bruttó kibocsátásokat $\left(\mathrm{GO}_{\mathrm{i}}, \mathrm{GO}_{\mathrm{e}}\right)$.

Az input-output tábla oldalszárnyának végső felhasználási komponenseire a jövedelemáramlási mátrix bemutatása után térünk vissza.

\section{A város és vonzáskörzetének jövedelemáramlási mátrixa}

A város és vonzáskörzete jövedelemáramlási vagy társadalmi elszámolási mátrixát az 5. táblázat mutatja.

Az input-output tábla alsó szárnyában keletkező vállalati és kormányzati bérek negatív előjellel szerepelnek a városi és vonzáskörzetbeli vállalatoknál és kormányzatnál a munkajövedelmek sorban. A bérek járulékai ugyanezen oszlopokban az adók sorban jelentkeznek kiáramlásként.

A tőkejövedelmek sorában és a vállalatok oszlopában mind a kifizetett, mind pedig a visszaforgatott vállalati jövedelmek negatív előjellel találhatók meg. A visszaforgatott profit a vállalati tőketételek között jelenik meg pozitív előjellel.

Modellünkben figyelembe vesszük, hogy a helyi vállalatok által generált munka- és tőkejövedelmek csak részben kerülnek helyi háztartásokhoz. A győri 


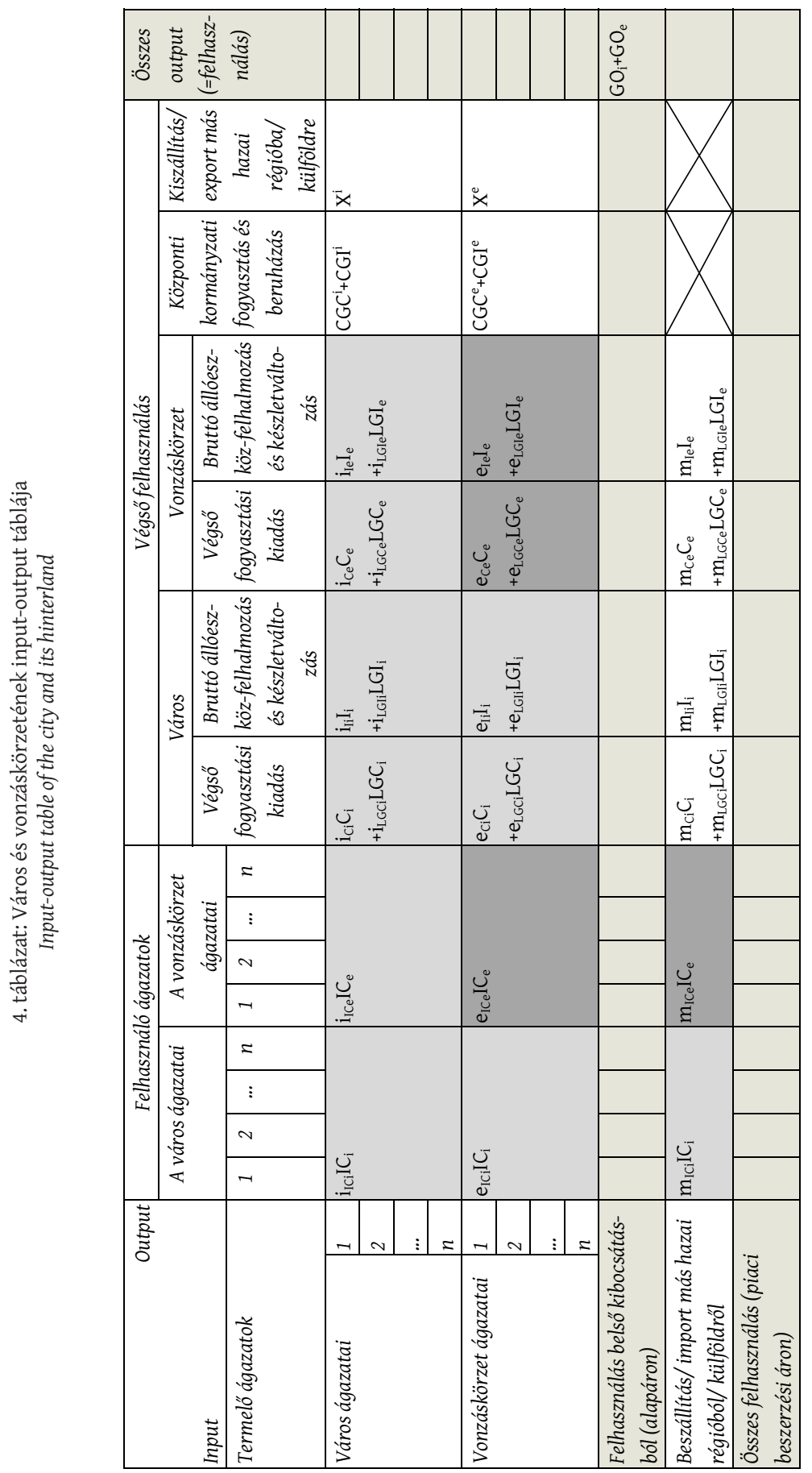


járműipari körzetben keletkező jövedelmek részben a körzet másik területére (városból a vonzáskörzetbe, vonzáskörzetből a városba), részben pedig a körzeten kívülre is kerülhetnek.

Ahogyan a régióban keletkező bérek egy része külföldre áramlik, a centrum és a periféria háztartásainak bérei és tőkejövedelmei is részben származhatnak a győri járműipari körzeten kívüli (központi) kormányzati vagy magángazdasági szereplőktől. WCGi-be tartozik például egy győri háztartás Budapesten dolgozó minisztériumi alkalmazottjának bére, XWe-be egy bábolnai lakos komáromi cégtől származó munkajövedelme, XDPe-be pedig egy Gyarmaton élő személy pápai vállalkozástól kapott osztaléka. ${ }^{3}$ Mivel ezek nem részei a körzet GDP-jének, ezért az input-output tábla alsó szárnyában meg sem jelennek.

A városi háztartások munkajövedelmeinél szereplő hosszú paraméteres formula azt fejezi ki, hogy a városi lakosság $i_{\mathrm{WFi}}$ arányban részesedik a városi vállalatok béreiből, $i_{\mathrm{WFe}}$ arányban a periféria vállalatainak béreiből, $\mathrm{i}_{\mathrm{WLGi}}$ arányban a helyi kormányzati bérekből, $i_{\text {wLGe }}$ arányban pedig a vonzáskörzet kormányzati bérkifizetéseiből (egy győri tanár például dolgozhat vonzáskörzetbeli iskolában is). Mindezek mellett kaphat kormányzati és vállalati béreket a győri járműipari körzeten kívülről is. A vonzáskörzet háztartásainál ugyanezeket a tételeket találjuk, csak az i hányadok és indexek helyett e-k, az e-k helyén pedig i jelölések szerepelnek. A körzetből a vállalati és kormányzati szektor béreinek régión kívülre áramló $m$ hányadai a külföldi vagy régión kívüli gazdasági szereplők oszlopában jelennek meg pozitív előjellel.

A jövedelemáramlási mátrixban külön sorban kezeljük az adókat és a transzfereket. A vállalatok és a háztartások a bérek járulékain felül központi és

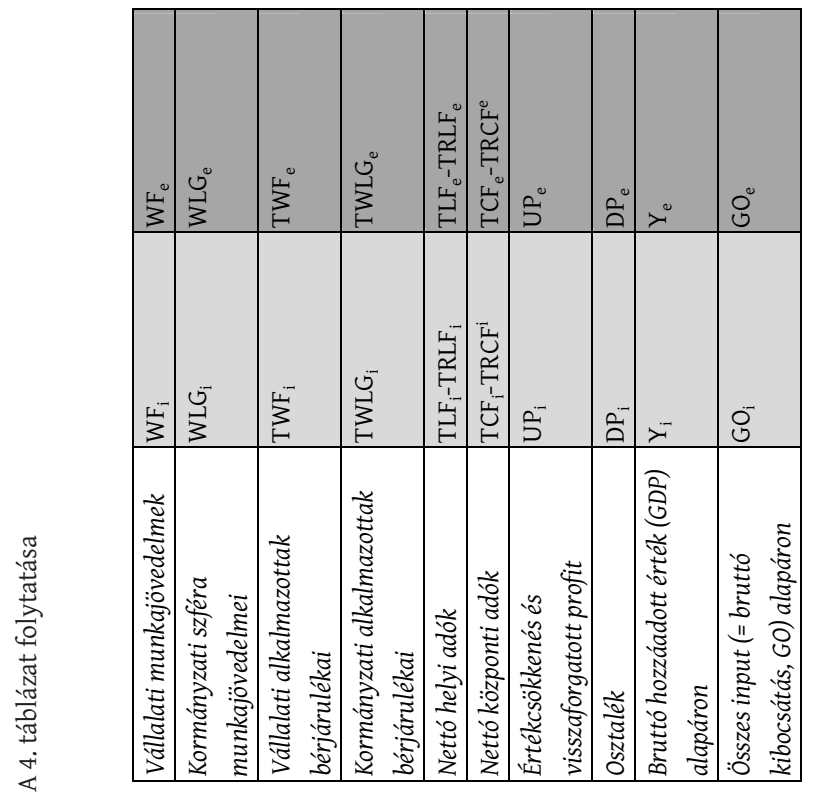




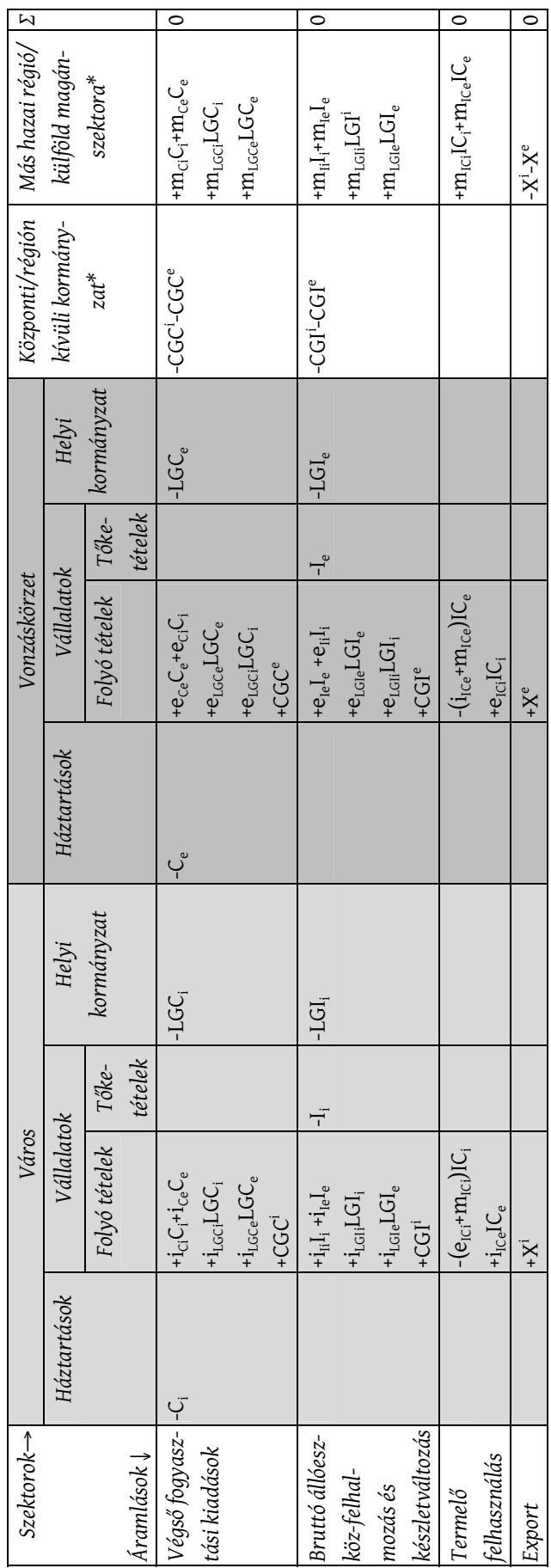




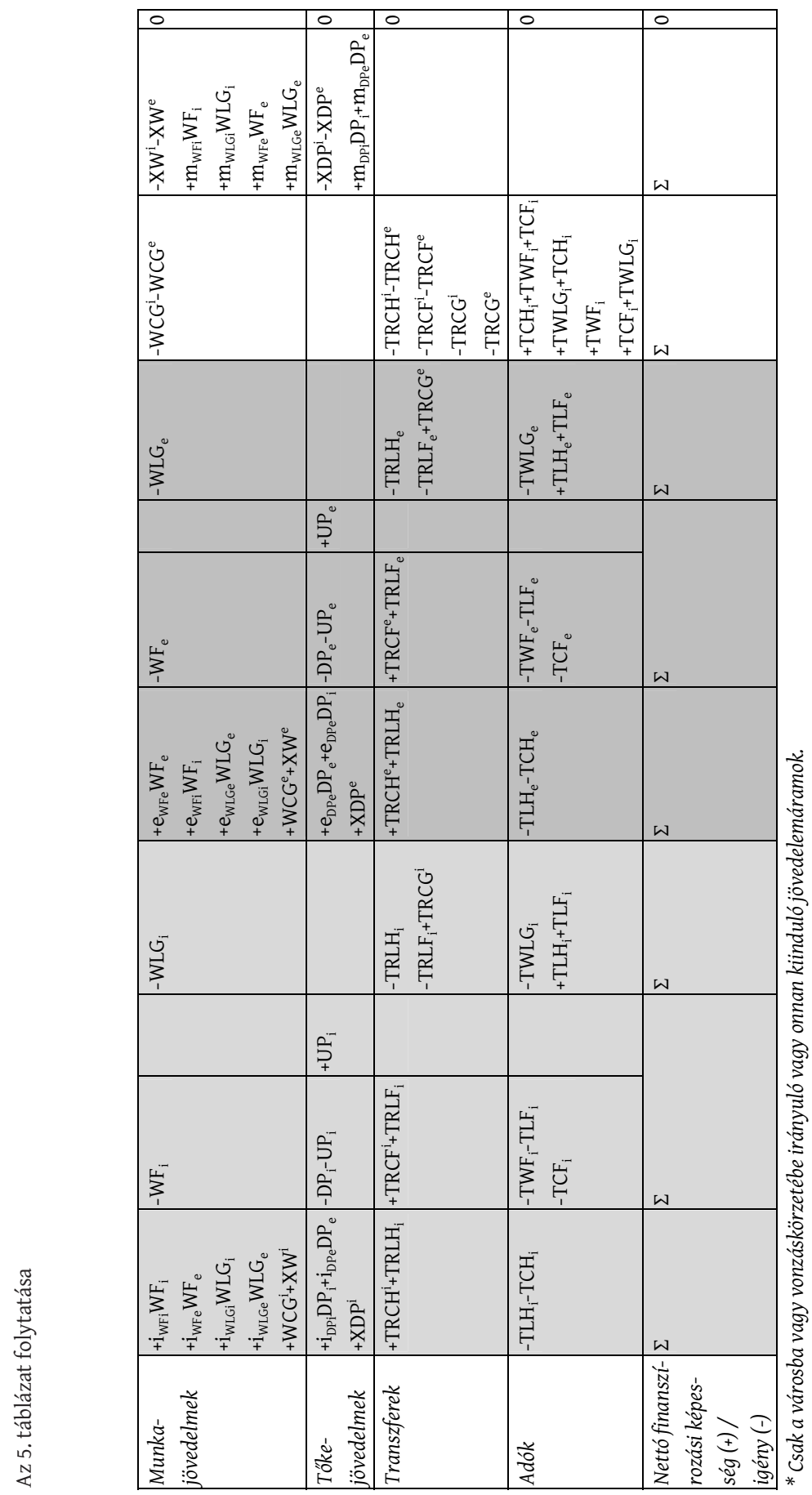


helyi adókat is fizetnek. A helyi adók a helyi kormányzathoz, a központi adók és járulékok a központi kormányzathoz áramlanak. A transzferek pozitív előjellel jelentkeznek a vállalatoknál és a háztartásoknál, negatívval a kibocsátónál. A helyi kormányzati szereplőknél a központi kormányzat által számukra jutatott támogatásokat (TRCG) is figyelembe vesszük.

A háztartások a rendelkezésre álló jövedelmeikből fogyasztanak. A háztartási fogyasztásra vonatkozó magatartási egyenletet nem fogalmaztunk meg, a legegyszerübb megoldás, hogy egy fogyasztási hányad segítségével a fogyasztást a rendelkezésre álló jövedelem lineáris függvényeként értelmezzük. A háztartásokon kívül a kormányzati szektor is fogyaszt (LGC, CGC), valamint beruházásokat (LGI, CGI) eszközöl. A beruházási keresletben (I) jelenik meg a vállalati állóeszköz-felhalmozás és a készletváltozás.

A végső felhasználási tételek régión belül keletkező részénél is alkalmazzuk az i, e és $m$ hányadokat. A városi lakosság fogyasztási kiadásainak $\left(\mathrm{C}_{\mathrm{i}}\right)$ például $\mathrm{i}_{\mathrm{Ci}}$ hányada helyi, $\mathrm{e}_{\mathrm{Ci}}$ hányada vonzáskörzetbeli vállalatok termékei iránt támaszt keresletet, $\mathrm{m}_{\mathrm{Ci}}$ része pedig a körzeten kívülre áramlik.

A vállalati folyó tételek oszlopaiban a város és vonzáskörzete közötti anyag- és árumozgást, valamint a régión kívülre áramló vagy onnan érkező termelő fogyasztást is megjelenítettük. A városi és vonzáskörzetbeli vállalatok bevételeinek és kiadásainak, valamint a területegységek GDP-jének elszámolása csakis így lesz teljes: egyrészt a más területegységektől származó közbülső termékek az adott területegység importját jelentik, amelyet a GDP-számítás során negatív előjellel kell figyelembe vennünk; másrészt a város és a vonzáskörzet közötti anyag- és árumozgás az értékesítő területegység számára éppúgy exportbevételt jelent, mint a társadalmi elszámolási mátrix következő sorában szereplő, a győri járműipari körzeten kívüli gazdasági szereplőkhöz kiszállított termékekből származó bevételek $\left(\mathrm{X}^{\mathrm{i}}, \mathrm{X}^{\mathrm{e}}\right)$.

A végső felhasználás tételeit visszavezetjük az input-output tábla oldalszárnyába. Az oldalszárnyat három fő részre bontottuk: város, vonzáskörzet, előbbieken kívüli belföldi vagy külföldi régiók. A város és a vonzáskörzet felhasználásain belül megkülönböztetjük a fogyasztási és beruházási célú végső felhasználást, a régión kívülre áramló tételeket pedig aszerint különítjük el, hogy a kormányzati vagy a magánszektorba irányulnak. A társadalmi elszámolási mátrixban megjelenő összes kiadási tételt be tudjuk sorolni a 4. táblázat input-output táblájának megfelelő cellájába.

A modellben alkalmazott jelöléseket a Függelékben foglaltuk össze.

\section{A továbbfejlesztés irányai és eszközei}

Tanulmányunk a győri járműipari körzet regionális tervezésre és előrejelzésre alkalmas makromodelljéhez vezető út első lépése. Áttekintettük a kapcsolódó 
szakirodalmat, ennek és saját elképzeléseinknek a vegyítésével kialakítottuk alapmodellünk szerkezetét.

A kutatás ezután következő része jelenti az igazi kihívást. Elsőként fel kell írnunk a győri járműipari körzet gyakorlati célokra is alkalmas, nagyjából 20-30 ágazatot tartalmazó input-output tábláját. ${ }^{4} \mathrm{~A}$ második feladat a társadalmi elszámolási mátrix kalibrálása, a harmadik pedig a magatartási egyenletek kidolgozása.

Az adatokkal való feltöltés, a modell pontos kalibrálása kérdőíves és nem kérdőíves technikák kombinált alkalmazását igényli. Bízunk benne, hogy hamarosan rendelkezésünkre állnak a győri járműipari körzetről szóló kutatás lakossági, intézményi és vállalati felméréseinek eredményei. Az ezekben elhelyezett, a háztartások jövedelmeire, fogyasztási szerkezetére, a helyi hányadokra, a repatriált vállalati nyereségekre, a beszállítások és az árbevétel regionális és ágazati megoszlására vonatkozó kérdésekre adott válaszok sokat segíthetnek a kalibrálásban. Kérdés, hogy ezek lefedik-e a teljes adatigényt. Amennyiben nem, érdemes elgondolkodni a kifejezetten a modell igényeit szolgáló, kis mintás lekérdezésen.

A hibrid adatgyüjtési technikák alkalmazása a meglévő kapcsolatok aktivizálását, újabb kapcsolatok kiépítését igényli a helyi adatszolgáltatókkal. Az üzleti szféra (Győri Nemzetközi Ipari Park, Győr-Moson-Sopron Megyei Kereskedelmi és Iparkamara, helyi vállalatok, pénzügyi intézmények, takarékszövetkezetek stb.) és a közszféra (Győr Megyei Jogú Város Önkormányzata, a vonzáskörzet településeinek önkormányzatai, a Széchenyi István Egyetem és más oktatási intézmények, a Petz Aladár Megyei Oktató Kórház és más egészségügyi intézmények, közigazgatási intézmények, TÁKISZ stb.) támogatására egyaránt számítunk. Az együttműködés eredményeként létrejövő makrogazdasági modell számukra is, mint ahogy a régió összes szereplője számára hasznos elemző- és tervezőeszköz lehet.

\section{Jegyzetek}

1 A táblázat összeállítása már nem ilyen egyszerű feladat. Terjedelmi okokból nem tárgyaljuk a forrás-, felhasználás- és levonótáblák és az input-output mátrix kapcsolatát, az input-output táblázatok típusait, valamint a táblarendszerek adatforrásait. Ezekről jó összefoglalást ad Boda, Koósné Balsay, Molnár (1989), KSH (2004a, 2004b, 2005), valamint Ambargis, Mead (2012). A tanulmány írásakor a 2008. évi a legfrissebb hozzáférhető nemzetgazdasági ágazati kapcsolati mérleg a KSH Tájékoztatási adatbázisában (www.ksh.hu).

2 A cambridge-i postkeynesi és az elsősorban francia, kanadai, olasz és spanyol közgazdászok által képviselt monetáris körforgási iskola különösen fontosnak tartja ezt a lehetőséget, amely a modern pénzgazdaság működésének jelenleg alkalmazott modelleinél jóval pontosabb és teljesebb leírását adhat (Dos Santos, Zezza 2004; Godley, Lavoie 2012; Graziani 2003; Lavoie 2001; Zezza 2004). Egy ilyen modell hazai alkalmazására mutat példát Koppány (2005).

3 Bábolna és Gyarmat a győri járműipari körzethez tartozik, Komárom és Pápa nem. A körzet területi lehatárolását Tóth (2013) végezte el. 
$4 \quad$ Egy háromszektoros változatra már készítettük számításokat, s ehhez kapcsolódóan igyekeztünk megbecsülni a győri járműipari körzet GDP-jét is, amely a modell kulcsváltozója. Ezeket az eredményeket külön tanulmányok formájában tervezzük publikálni, a projekt tanulmánykötetében pedig várhatóan teljes kutatási jelentésünk megjelenik.

\section{Irodalom}

Ambargis, Z. O., Mead, C. I. (2012): RIMS II. An essential tool for regional developers and planners. Bureau of Economic Analysis, Washington

Armstrong, H., Taylor, J. (2000): Regional economics and policy. Third edition. Blackwell, Oxford

Augusztinovics, M. (1996): Miről szól az input-output modell? Közgazdasági Szemle, április, 315-320.

Boda Gy., Koósné Balsay É., Molnár I. (1989): Az ágazati kapcsolatok mérlegének összeállítása Magyarországon. Statisztikai Szemle, 6., 584-598.

Bussolo, M., Chemingui, M., O'Connor, D. (2003): A multi-region social accounting matrix (1995) and regional environmental general equilibrium model for India (REGEMI). OECD Development Centre Working Paper, 213.

Carlberg, M. (1978): Ein interregionales, multisektorales Wachstumsmodell - dargestellt für die Bundesrepublik Deutschland. Vandenhoeck\&Ruprecht, Göttingen

Chenery, H. B. (1953): Regional analysis. In: Chenery, H., Clark, P. B. (eds.): The structure and growth of the Italian economy. US Mutual Security Agency Special Mission to Italy for Economic Cooperation, Rome

Daley, W. M., Ehrlich, E. M., Landefeld, S. J., Barker, B. L. (1997): Regional multipliers. A user handbook for the regional input-output modelling system (RIMS II). Third edition. U.S. Department of Commerce, Economics and Statistics Administration, Bureau of Economic Analysis, Washington

Dos Santos, C. H., Zezza, G. (2004): A post-keynesian stock-flow consistent macroeconomic growth model: preliminary results. The Levy Economic Institute Working Paper, 402.

Farkas, P., Koppány, K. (2006): Közgazdaságtan. Mikro- és makroökonómiai alapismeretek mindennapi használatra. Universitas-Győr Kht., Győr

Fodor, L., Illés I. (1968): A Budapesten belüli ágazatok közötti kölcsönhatások vizsgálata. Országos Tervhivatal, Tervgazdasági Intézet, Budapest

Glasmeier, A. (2004): Geographic intersections of regional science: reflections on Walter Isard's contributions to geography. Journal of Geographical Systems, 1., 27-41.

Godley, W., Lavoie, M. (2012): Monetary economics. An integrated approach to credit, money, income, production and wealth. Second edition. Palgrave Macmillan, Basingstoke

Graziani, A. (2003): The monetary theory of production. Cambridge University Press, Cambridge

Harrigan, F., McGilvray, J., McNicoll, I. (1981): The estimation of interregional trade flows. Journal of Regional Science, 1., 65-78.

Isard, W. (1951): Interregional and regional input-output analysis: a model of a space-economy. Review of Economic and Statistics, november, 318-329.

Koppány, K. (2005): A gazdasági növekedés és a pénzügyi közvetítés mélységének összefüggései stockflow konzisztens endogén pénz modellben. In: Solt K., Böhm A., Farkas Sz., Ferenczi Z., Honvári J., Józsa L., Ablonczyné Mihályka L., Rechnitzer J. (szerk.) Ünnepi dolgozatok. 15 éves a győri közgazdászképzés. Széchenyi István Egyetem Gazdaság- és Társadalomtudományi Intézet, Győr, 98-106.

KSH [Központi Statisztikai Hivatal] (2004a): A gazdaság szerkezete az ágazati kapcsolati mérlegek alapján. KSH, Budapest

KSH [Központi Statisztikai Hivatal] (2004b): Ágazati kapcsolatok mérlege, 2000. KSH, Budapest

KSH [Központi Statisztikai Hivatal] (2005): Az ágazati kapcsolatok mérlegének matematikai feldolgozása, 2000. KSH, Budapest

Kuhar, A., Golmenova K., A., Erjavec, E., Kožar, M., Cör, T. (2009): Regionalization of the social accounting matrix, common agricultural policy regional impact - the rural development dimension. CAPRI-RD, University of Ljubjana 
Lavoie, M. (2001): Endogenous money in a coherent stock-flow framework. Department of Economics, University of Ottawa Working Paper, 325.

Lengyel I., Rechnitzer J. (2004): Regionális gazdaságtan. Dialóg Campus Kiadó, Budapest, Pécs

Martana, K., Evison, D., Lennox, J., Manley, B. (2012): Constructing a regional social accounting matrix using non survey method for CGE modeling. New Zealand Agricultural \& Resource Economics Society, School of Forestry, University of Canterbury, Landcare Research. Paper presented at the 2012 NZARES Conference

Miller, R. E. (1998): Regional and interregional input-output analysis. In: Isard, W., Azin, I. J., Drennan M. P., Miller, R. E., Saltzman, S., Thorbecke, E. (eds.): Methods of interregional and regional analysis. Ashgate, Aldershot, 41-134.

Miller, R. E., Blair, P. D. (2009): Input-output analysis. Foundations and extensions, Second edition. Cambridge University Press, Cambridge

Moses, L. (1955): The stability of interregional trading patterns and input-output analysis. American Economic Review, 5., 803-832.

Punt, C., Pauw, K., van Schoor, M., Gilimani, B., Rantho, L., McDonald, S., Chant, L. (2006): Compiling national, multiregional and regional social accounting matrices for South Africa. Provincial DecisionMaking Enabling (PROVIDE) Project, Elsenburg

Rechnitzer, J. (1984): A területi gazdasági szerkezetek és kapcsolatok modellezése. MTA Dunántúli Tudományos Intézet, Pécs (A Magyar Tudományos Akadémia Dunántúli Tudományos Intézetének kutatási eredményei 1981-1985; 10.)

Richardson, H. W. (1973): Input-output and regional economics. Weidenfeld and Nicolson, London

Riefler, R., Tiebout, C. (1970): Interregional input-output: an empirical California-Washington model. Journal of Regional Science, 2., 135-152.

Sargento, A. L. M. (2009): Introducing input-output analysis at the regional level: Basic notions and specific issues. Regional Economics Applications Laboratory, School of Technology and Management, Polytechnic Institute of Leiria, http://www.real.illinois.edu/d-paper/09/09-t-4.pdf (Letöltés: 2013. június 28.)

Smahó M. (2007): Kísérlet egy régió szimulációs modelljének kidolgozására. Tér és Társadalom, 1., 117-129.

Tóth P. (2013): A Győri Járműipari Körzet lehatárolásának módszertani problémái. „Növekedés és egyensúly", Kautz Gyula Emlékkonferencia. Győr, 2013. június 11.

Zalai, E. (2000): Matematikai közgazdaságtan. A korszerü mikroökonómiai elemzés klasszikus és neoklasszikus szemléletü modelljei. KJK-KERSZÖV, Budapest

Zezza, G. (2004): Some simple, consistent models of monetary circuit. The Levy Economic Institute Working Paper, 405.

http://www.implan.com/ (Letöltés: 2013. július 25.) 
Függelék: a győri járműipari körzet alapmodelljében használt jelölések

\begin{tabular}{|c|c|}
\hline i & városban maradó / városba áramló hányad \\
\hline $\mathrm{e}$ & vonzáskörzetben maradó / vonzáskörzetbe áramló hányad \\
\hline$\underline{\mathrm{m}}$ & más régióba / külföldre áramló hányad \\
\hline$\overline{\mathrm{WF}_{\mathrm{i}}}$ & városban működő vállalatok által fizetett bérek \\
\hline $\mathrm{WF}_{\mathrm{e}}$ & vonzáskörzetben müködő vállalatok által fizetett bérek \\
\hline$\overline{W L G_{i}}$ & városban dolgozó kormányzati alkalmazottak bérei \\
\hline $\mathrm{WLG}_{\mathrm{e}}$ & vonzáskörzetben dolgozó kormányzati alkalmazottak bérei \\
\hline $\mathrm{WCG}^{\mathrm{i}}$ & régión kívül dolgozó, városban lakó kormányzati alkalmazottak bérei \\
\hline$\overline{\text { WCG }}{ }^{\mathrm{e}}$ & régión kívül dolgozó, vonzáskörzetben lakó kormányzati alkalmazottak bérei \\
\hline $\mathrm{XW}^{\mathrm{i}}$ & régión kívül működő vállalatnál dolgozó, városban lakó alkalmazottak bérei \\
\hline $\mathrm{XW}^{\mathrm{e}}$ & régión kívül működő vállaltnál dolgozó, vonzáskörzetben lakó alkalmazottak bérei \\
\hline $\mathrm{DP}_{\mathrm{i}}$ & városi vállalatok osztalékként kifizetett profitja \\
\hline$\overline{\mathrm{DP}_{\mathrm{e}}}$ & vonzáskörzetben működő vállalatok osztalékként kifizetett profitja \\
\hline $\mathrm{UP}_{\mathrm{i}}$ & városi vállalatok visszaforgatott profitja \\
\hline $\mathrm{UP}_{\mathrm{e}}$ & vonzáskörzetben müködő vállalatok visszaforgatott profitja \\
\hline$\overline{\mathrm{XDP}^{\mathrm{i}}}$ & régión kívüli vállalatok városban lakó tulajdonos számára osztalékként kifizetett profitja \\
\hline$\overline{\mathrm{XDP}}$ & $\begin{array}{l}\text { régión kívüli vállalatok vonzáskörzetben lakó tulajdonos számára osztalékként kifizetett } \\
\text { profitja }\end{array}$ \\
\hline $\mathrm{TRCH}^{\mathrm{i}}$ & városi lakosság központi kormányzattól kapott transzferjövedelmei \\
\hline $\mathrm{TRCH}^{\mathrm{e}}$ & vonzáskörzetben élő lakosság központi kormányzattól kapott transzferjövedelmei \\
\hline $\mathrm{TRLH}_{\mathrm{i}}$ & városi lakosság helyi önkormányzattól kapott transzferjövedelmei \\
\hline $\mathrm{TRLH}_{\mathrm{e}}$ & vonzáskörzetben élő lakosság helyi önkormányzatoktól kapott transzferjövedelmei \\
\hline TRCF $^{\mathrm{i}}$ & városi vállalatok központi kormányzattól kapott transzferei \\
\hline TRCF & vonzáskörzetben működő vállalatok központi kormányzattól kapott transzferei \\
\hline $\mathrm{TRLF}_{\mathrm{i}}$ & városi vállalatok helyi önkormányzattól kapott transzferei \\
\hline $\mathrm{TRLF}_{\mathrm{e}}$ & vonzáskörzetben müködő vállalatok helyi önkormányzatoktól kapott transzferei \\
\hline TRCG ${ }^{\mathrm{i}}$ & városi önkormányzat központi kormányzattól kapott transzferei \\
\hline TRCG & $\begin{array}{l}\text { vonzáskörzetben működő helyi önkormányzatok központi kormányzattól kapott } \\
\text { transzferei }\end{array}$ \\
\hline $\mathrm{TLH}_{\mathrm{i}}$ & városi háztartások helyi adói \\
\hline $\mathrm{TCH}_{\mathrm{i}}$ & városi háztartások központi adói \\
\hline $\mathrm{TLH}_{\mathrm{e}}$ & vonzáskörzetbeli háztartások helyi adói \\
\hline $\mathrm{TCH}_{\mathrm{e}}$ & vonzáskörzetbeli háztartások központi adói \\
\hline $\mathrm{TWF}_{\mathrm{i}}$ & városi vállalatok által fizetendő bérjárulékok \\
\hline $\mathrm{TLF}_{\mathrm{i}}$ & városi vállalatok helyi adói \\
\hline $\mathrm{TCF}_{\mathrm{i}}$ & városi vállalatok központi adói \\
\hline $\mathrm{TWF}_{\mathrm{e}}$ & vonzáskörzetben müködő vállalatok által fizetendő bérjárulékok \\
\hline $\mathrm{TLF}_{\mathrm{e}}$ & vonzáskörzetben müködő vállalatok helyi adói \\
\hline $\mathrm{TCF}_{\mathrm{e}}$ & vonzáskörzetben müködő vállalatok központi adói \\
\hline
\end{tabular}




\begin{tabular}{ll}
$\mathrm{C}_{\mathrm{i}}$ & városi háztartások fogyasztási kiadásai \\
\hline $\mathrm{C}_{\mathrm{e}}$ & vonzáskörzetbeli háztartások fogyasztási kiadásai \\
\hline $\mathrm{LGC}_{\mathrm{i}}$ & városi kormányzati fogyasztás \\
\hline $\mathrm{LGC}_{\mathrm{e}}$ & vonzáskörzetbeli kormányzati fogyasztás \\
\hline $\mathrm{CGC} \mathrm{C}^{\mathrm{i}}$ & városba áramló központi / régión kívüli kormányzati fogyasztási kiadások \\
\hline $\mathrm{CGC} C^{\mathrm{e}}$ & vonzáskörzetbe áramló központi / régión kívüli kormányzati fogyasztási kiadások \\
\hline $\mathrm{I}_{\mathrm{i}}$ & városi vállalatok beruházási kiadásai \\
\hline $\mathrm{I}_{\mathrm{e}}$ & vonzáskörzetbeli vállalatok beruházási kiadásai \\
\hline $\mathrm{LGI}_{\mathrm{i}}$ & városi kormányzati beruházási kiadások \\
\hline $\mathrm{LGI}_{\mathrm{e}}$ & vonzáskörzetbeli kormányzati beruházási kiadások \\
\hline $\mathrm{CGI}^{\mathrm{i}}$ & városba áramló központi / régión kívüli kormányzati beruházási kiadások \\
\hline $\mathrm{CGI}^{\mathrm{e}}$ & vonzáskörzetbe áramló központi / régión kívüli kormányzati beruházási kiadások \\
\hline $\mathrm{IC}_{\mathrm{i}}$ & városi vállalatok termelő fogyasztása \\
\hline $\mathrm{IC}_{\mathrm{e}}$ & vonzáskörzetbeli vállalatok termelő fogyasztása \\
\hline $\mathrm{X}^{\mathrm{i}}$ & városi gazdaság exportbevételei (régión kívülre / külföldre történő kiszállítás) \\
\hline $\mathrm{X}^{\mathrm{e}}$ & vonzáskörzet exportbevételei (régión kívülre / külföldre történő kiszállítás) \\
\hline &
\end{tabular}




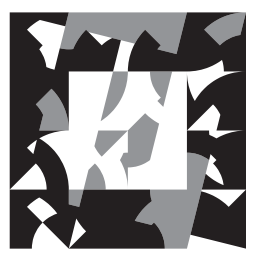

TÉR ÉS TÁRSADALOM | SPACE AND SOCIETY 